\title{
Slow Relaxation of the Magnetization in Oximato-Bridged Heterobimetallic Copper(II)-Manganese(III) Chains
}

\author{
Rafael Ruiz, ${ }^{a, b}$ Isabel Castro, ${ }^{a}$ Emilio Pardo, ${ }^{a}$ Jesús Ferrando-Soria, ${ }^{a}$ Joan Cano,,${ }^{a, b}$ \\ Francesc Lloret ${ }^{a}$ and Miguel Julve ${ }^{*, a}$
}

\author{
${ }^{a}$ Departament de Química Inorgànica/Instituto de Ciencia Molecular (ICMol), \\ Universitat de València, C/ Catedrático José Beltrán 2, 46980 Paterna, València, Spain
}

${ }^{b}$ Fundación General de la Universitat de València (FGUV), Amadeo de Saboya 4, 46010 València, Spain

\begin{abstract}
O uso de oximato-complexos de cobre(II), $\left[\mathrm{Cu}(\mathrm{Hdeg})_{2}\right]\left(\mathrm{H}_{2} \mathrm{deg}=\right.$ dietilglioxima $)$, $\left[\mathrm{Cu}(\mathrm{Hmeg})_{2}\right]$ $\left(\mathrm{H}_{2} \mathrm{meg}=\right.$ metiletilglioxima $)$ e $\left[\mathrm{Cu}(\mathrm{Hdmg})_{2}\right]\left(\mathrm{H}_{2} \mathrm{dmg}=\right.$ dimetilglioxima $)$, como ligantes em reações com acetato de manganês(II) em metanol forneceu compostos heterobimetálicos de fórmula $\left[\mathrm{MnCu}(\mathrm{deg})_{2}\left(\mathrm{CH}_{3} \mathrm{COO}\right)\left(\mathrm{H}_{2} \mathrm{O}\right)_{2}\right](\mathbf{1}),\left[\mathrm{MnCu}(\mathrm{meg})_{2}\left(\mathrm{CH}_{3} \mathrm{COO}\right)\left(\mathrm{H}_{2} \mathrm{O}\right)_{2}\right](2)$ e $\left[\mathrm{MnCu}(\mathrm{dmg})_{2}\left(\mathrm{CH}_{3} \mathrm{COO}\right)\left(\mathrm{H}_{2} \mathrm{O}\right)_{2}\right](3)$, com oxidação do íon manganês(II) a manganês(III) na presença de ar. Na ausência de monocristais para análise por difratometria de raios X, técnicas de absorção de raios X (EXAFS e XANES) foram usadas a $40 \mathrm{~K}$ para caracterização estrutural de 1-3. A análise dos dados de absorção de raios X revelou que 1-3 apresentam cadeias bimetálicas de íons $\mathrm{Cu}^{\mathrm{II}}$ e $\mathrm{Mn}^{\mathrm{III}}$ ligados por pontes oximato, em ambiente octaédrico $\left(\mathrm{CuN}_{4} \mathrm{O}_{2}\right.$ e $\left.\mathrm{MnO}_{6}\right)$ alongado. Os estudos de propriedades magnéticas de 1-3 revelaram um comportamento metamagnético devido à coexistência de acoplamentos ferromagnéticos intracadeias fortes $[J=+52.5(\mathbf{1}),+49.1(2) \mathrm{e}$ $\left.+52.1 \mathrm{~cm}^{-1}(\mathbf{3})\right]$ e interações antiferromagnéticas intercadeias fracas $[j=-0.070(\mathbf{1}),-0.075(\mathbf{2})$ e $\left.-0.078 \mathrm{~cm}^{-1}(3)\right]$. A ortogonalidade estrita entre o orbital magnético do cobre(II) e aquele do centro magnético de manganês(III), junto com a conhecida habilidade do grupo oximato em mediar interações magnéticas quando atua como ponte entre dois íons metálicos, é responsável pela forte interação ferromagnética intracadeia em 1-3. Medidas de susceptibilidade sob corrente alternada realizadas para 1-3 em temperatura baixa e sob campo magnético dc igual a zero revelaram uma dependência do sinal ac fora de fase com a frequência do campo oscilante, como esperado para magnetos do tipo single-chain.
\end{abstract}

The use of the oximato-containing copper(II) complexes, $\left[\mathrm{Cu}(\mathrm{Hdeg})_{2}\right]\left(\mathrm{H}_{2} \mathrm{deg}=\right.$ diethylglyoxime $)$, $\left[\mathrm{Cu}(\mathrm{Hmeg})_{2}\right]\left(\mathrm{H}_{2} \mathrm{meg}=\right.$ methylethylglyoxime $)$ and $\left[\mathrm{Cu}(\mathrm{Hdmg})_{2}\right]\left(\mathrm{H}_{2} \mathrm{dmg}=\right.$ dimethylglyoxime $)$, as ligands toward manganese(II) acetate in methanol afforded the heterobimetallic compounds of formula $\left[\mathrm{MnCu}(\mathrm{deg})_{2}\left(\mathrm{CH}_{3} \mathrm{COO}\right)\left(\mathrm{H}_{2} \mathrm{O}\right)_{2}\right](\mathbf{1})$, $\left[\mathrm{MnCu}(\mathrm{meg})_{2}\left(\mathrm{CH}_{3} \mathrm{COO}\right)\left(\mathrm{H}_{2} \mathrm{O}\right)_{2}\right]$ (2) and $\left[\mathrm{MnCu}(\mathrm{dmg})_{2}\left(\mathrm{CH}_{3} \mathrm{COO}\right)\left(\mathrm{H}_{2} \mathrm{O}\right)_{2}\right](3)$ where the starting manganese(II) ion was oxidized to manganese(III) by air. In the lack of single crystals suitable for X-ray diffraction analysis, X-ray absorption techniques (EXAFS and XANES) at $40 \mathrm{~K}$ were used for the structural characterization of 1-3. The analysis of the X-ray absorption data reveals that 1-3 are oximato-bridged $\mathrm{Cu}^{\mathrm{II}}-\mathrm{Mn}^{\mathrm{III}}$ bimetallic chains with elongated octahedral $\mathrm{CuN}_{4} \mathrm{O}_{2}$ and $\mathrm{MnO}_{6}$ surroundings. The study of the magnetic properties of 1-3 reveals a metamagnetic-like behavior due to the coexistence of strong intrachain ferromagnetic couplings $\left[J=+52.5(\mathbf{1}),+49.1(2)\right.$ and $\left.+52.1 \mathrm{~cm}^{-1}(3)\right]$ and weak interchain antiferromagnetic interactions $\left[j=-0.070(\mathbf{1}),-0.075(\mathbf{2})\right.$ and $\left.-0.078 \mathrm{~cm}^{-1}(\mathbf{3})\right]$. The strict orthogonality between the magnetic orbital of the copper(II) ion and those of the manganese(III) center, together with the well known ability of the oximato group to mediate magnetic interactions when acting as a bridge between two metal ions, account for the relatively strong intrachain ferromagnetic coupling in 1-3. Alternating current susceptibility measurements for 1-3 in the low temperature range under zero dc magnetic field reveal a frequency-dependence of the out-of-phase ac signal as expected for single chain magnets.

Keywords: metal oximates, heterobimetallic complexes, complex as ligand strategy, exchange coupling, single chain magnets

\footnotetext{
*e-mail: miguel.julve@uv.es
} 


\section{Introduction}

Since the first report concerning the use of the dimethylglyoxime $\left(\mathrm{H}_{2} \mathrm{dmg}\right)$ as a reagent for nickel(II), ${ }^{1}$ oximes as ligands have been widely used in coordination chemistry. Although the primary attention on them was devoted to preparative routes of coordination compounds and to analytical chemistry purposes, their metal-mediated reactions and high-nuclearity, exchange-coupled metal clusters have caught the eyes of different research teams in the last two decades. ${ }^{2,3}$

Restricting ourselves to the field of molecular magnetism, the oxime group, $>\mathrm{C}=\mathrm{NOH}$, has two characteristics that make it very appealing: (i) its ability to act as a bridge between two different metal ions after deprotonation, to afford a great variety of heterobimetallic compounds, [M-( $\left.\left.\mu-\mathrm{NO}_{\text {oximato }}\right)-\mathrm{M}^{\prime}\right]$, and (ii) its remarkable capability to mediate very strong magnetic interactions between the spin carriers bridged by the double $\mathrm{NO}_{\text {oximato }}$ pathway. As illustrative examples of the great efficiency of this exchange pathway to mediate electronic interactions, one can cite the practically diamagnetic character at room temperature of a family of bis(oximato)-bridged binuclear copper(II) complexes with an intramolecular copper-copper separation of $c a .3 .5 \AA$ (values of $J$ up to $-1000 \mathrm{~cm}^{-1}$ with the spin Hamiltonian being defined as $\left.\hat{H}=-J \hat{S}_{1} \cdot \hat{S}_{2}\right) \cdot{ }^{4-11}$ The mechanism of the exchange interaction between copper(II) ions through this type of bridge is well understood. The unpaired electron of each copper(II) ion is defined by a $\mathrm{d}_{x^{2}-y^{2}}$-type orbital and it is delocalized toward the oximato bridges. This situation is illustrated in Scheme 1, which shows the good $\sigma$-in plane overlap $(S)$ between the coplanar $\mathrm{d}_{x^{2}-y^{2}}$ magnetic orbitals in each $\mathrm{Cu}-\mathrm{N}-\mathrm{O}-\mathrm{Cu}$ arm. According to the model of localized non-orthogonal magnetic orbitals proposed by Kahn and Briat, ${ }^{12}$ the value of the antiferromagnetic contribution for a binuclear copper(II) complex is proportional to the square of the overlap integral $\left(S^{2}\right)$ and a large antiferromagnetic coupling is expected, as observed.

These characteristics of the oximato bridge make it a good candidate to design heterobimetallic single chain magnets (SCMs), that are one-dimensional compounds
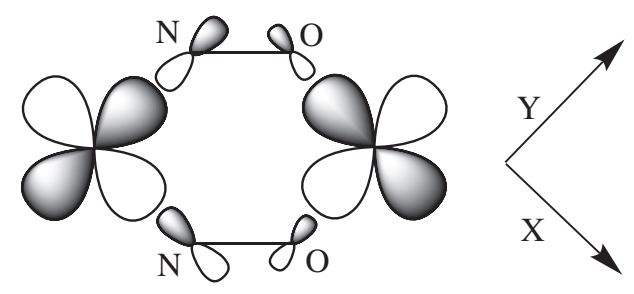

Scheme 1. which exhibit slow relaxation of the magnetization and hysteresis effects. ${ }^{13-17}$ Slow relaxation of the magnetization in a ferromagnetic Ising chain was first predicted by Glauber in 1965 and, after his theory, ${ }^{18}$ the conditions to be fulfilled by a chain compound to be a SCM are: (i) the system must behave as a 1D Ising ferro- or ferrimagnet and (ii) the chains have to be well isolated from each other in order to hamper the transition to 3D magnetic ordering. Since this prediction, several families of SCMs have been prepared and magnetostructurally investigated, the bridging ligands being organic radicals, ${ }^{17}$ single oximato/double phenoxo, ${ }^{19}$ cyanido, ${ }^{20}$ azido, ${ }^{21}$ oxalato, ${ }^{22}$ oxamato, ${ }^{23}$ bis(2-pyridylcarbonyl) amidato, ${ }^{24}$ carboxylato ${ }^{25}$ and phosphato/phosphinato. ${ }^{26}$

In an attempt to create SCMs working at high temperatures, we decided to take advantage of the strong magnetic coupling across the bis-dioximato bridge to design heterobimetallic $\mathrm{Cu}^{\mathrm{II}}-\mathrm{Mn}^{\mathrm{III}}$ chains where the anisotropy would be ensured by the presence of the manganese(III) ion. The use of a complex as ligand allowed us to achieve this goal, the starting building block being the species shown in Scheme 2 . Their reaction with manganese(II) acetate in methanol in air afforded the compounds of formula $\left[\mathrm{MnCu}(\mathrm{deg})_{2}\left(\mathrm{CH}_{3} \mathrm{COO}\right)\right.$ $\left.\left(\mathrm{H}_{2} \mathrm{O}\right)_{2}\right]$ (1), $\left[\mathrm{MnCu}(\mathrm{meg})_{2}\left(\mathrm{CH}_{3} \mathrm{COO}\right)\left(\mathrm{H}_{2} \mathrm{O}\right)_{2}\right]$ (2) $\left[\mathrm{MnCu}(\mathrm{dmg})_{2}\left(\mathrm{CH}_{3} \mathrm{COO}\right)\left(\mathrm{H}_{2} \mathrm{O}\right)_{2}\right](\mathbf{3})\left[\mathrm{H}_{2} \mathrm{deg}=\right.$ diethylglyoxime, $\mathrm{H}_{2} \mathrm{meg}=$ methylethylglyoxime and $\mathrm{H}_{2} \mathrm{dmg}=$ dimethylglyoxime]. Their preparation, structural characterization and magnetic investigation are reported herein. A previous communication with the preliminary magnetic study of $\mathbf{3}$ was published elsewhere. ${ }^{27}$

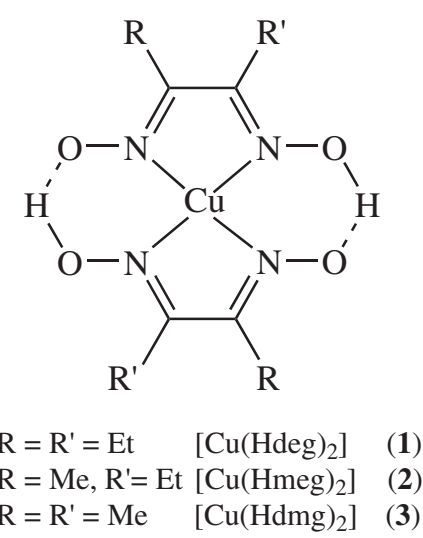

\section{Experimental}

Scheme 2.

Reagents

Manganese(II) acetate dihydrate, copper(II) nitrate trihydrate, potassium hydroxide, $\mathrm{NH}_{2} \mathrm{OH} \cdot \mathrm{HCl}$, pentane2,3-dione, hexane-3,4-dione and $\mathrm{H}_{2} \mathrm{dmg}$ were purchased 
from commercial sources and used as received. The complexes $\left[\mathrm{Cu}(\mathrm{Hdmg})_{2}\right],\left[\mathrm{Cu}(\mathrm{Hmeg})_{2}\right]$ and $\left[\mathrm{Cu}(\mathrm{Hdeg})_{2}\right]$ were prepared by reacting the freshly prepared copper(II) hydroxide with the corresponding vic-dioxime in methanol, as reported in the literature. ${ }^{28,29}$ Elemental analysis $(\mathrm{C}, \mathrm{H}, \mathrm{N})$ were performed by the Microanalytical Service of the Universidad Autónoma de Madrid. A value of 1:1 for the Cu:Mn molar ratio in 1-3 was determined by means of a Philips XL-30 scanning electron microscope equipped with an X-ray microanalysis system from the Servicio Central de Soporte a la Investigación (SCSIE) at the Universitat de València.

Preparation of $\left[\mathrm{MnCu}(\mathrm{deg})_{2}\left(\mathrm{CH}_{3} \mathrm{COO}\right)\left(\mathrm{H}_{2} \mathrm{O}\right)_{2}\right]$ (1), [ $\left.\mathrm{MnCu}(\mathrm{meg})_{2}\left(\mathrm{CH}_{3} \mathrm{COO}\right)\left(\mathrm{H}_{2} \mathrm{O}\right)_{2}\right]$ (2) and $\left[\mathrm{MnCu}(\mathrm{dmg})_{2}\left(\mathrm{CH}_{3} \mathrm{COO}\right)\left(\mathrm{H}_{2} \mathrm{O}\right)_{2}\right](3)$

Compounds 1-3 were synthesized by following the same preparative method, which consists of reacting methanolic solutions of the neutral copper(II)-containing oximato complex and manganese(II) acetate in air. The air oxidation of manganese(II) to manganese(III) occurred in the reaction time. A typical preparation is as follows: manganese(II) acetate dihydrate $(0.5 \mathrm{mmol}, 0.105 \mathrm{~g})$ is added to a warm methanolic solution $\left(40 \mathrm{~cm}^{3}\right)$ of $\left[\mathrm{Cu}(\mathrm{Hdmg})_{2}\right](0.5 \mathrm{mmol}$, $0.147 \mathrm{~g}$ ) under continuous stirring. A black polycrystalline powder of $\mathbf{3}$ separated from the dark mother liquor on standing in a hood at room temperature for $1 \mathrm{~h}$. In all three cases, the samples obtained diffract poorly and all our attempts to grow X-ray quality crystals of 1-3 were unsuccessful. The yield for $\mathbf{1 - 3}$ is $c a$. $90 \%$. Elemental Analysis: Calculated for $\mathrm{C}_{14} \mathrm{H}_{27} \mathrm{CuMnN}_{4} \mathrm{O}_{8}$ (1): C, 33.79; H, 5.43; N, 11.25. Found: C, 33.58; H, 5.35; N, $11.16 \%$. Calculated for $\mathrm{C}_{12} \mathrm{H}_{23} \mathrm{CuMnN}_{4} \mathrm{O}_{8}$ (2): C, 30.69; H, 4.90; N, 11.92. Found: C, 30.51; H, 4.83; N, 11.83\%. Calculated for $\mathrm{C}_{10} \mathrm{H}_{19} \mathrm{CuMnN}_{4} \mathrm{O}_{8}(3)$ : C, 27.19; H, 4.34; N, 12.68 . Found: C, 26.95; H, 4.49; N, 12.64\%.

\section{Magnetic measurements}

Magnetic susceptibility measurements on polycrystalline samples of 1-3 were performed with a SQUID magnetometer in the temperature range 1.9-295 K under applied dc magnetic fields covering the range $0-5 \mathrm{~T}$. Isothermal magnetization measurements $[2.0 \leq T \leq 7.0$ (1), $2.0 \leq T \leq 11.0$ (2) and $2.0 \leq T \leq 10.0 \mathrm{~K}(3)$ ] were carried out as a function of the dc magnetic field up to $5 \mathrm{~T}$ (the maximum available magnetic field in our device). Alternating current magnetic susceptibility measurements were carried out at zero static field and under an oscillating field of $\pm 1 \mathrm{G}$ at different frequencies. Corrections for the diamagnetism of the constituent atoms in $\mathbf{1 - 3}$ were estimated from Pascal's constants ${ }^{30}$ as $-248 \times 10^{-6}(\mathbf{1}),-225 \times 10^{-6}(\mathbf{2})$ and
$-201 \times 10^{-6} \mathrm{~cm}^{3} \mathrm{~mol}^{-1}$ (3) (per $\mathrm{Cu}^{\mathrm{II}} \mathrm{Mn}^{\mathrm{III}}$ pair). Magnetic susceptibility data were also corrected for the temperatureindependent paramagnetism $\left(60 \times 10^{-6} \mathrm{~cm}^{3} \mathrm{~mol}^{-1} \mathrm{per}\right.$ copper(II) ion) and for the magnetization of the sample holder (a plastic bag).

\section{$X$-ray absorption data collection and processing}

The XANES (X-ray absorption near edge structures) and EXAFS (extended X-ray absorption fine structures) spectra for 1-3, along with their corresponding copper(II) mononuclear precursors, were collected at LURE (Laboratoire d'Utilisation du Rayonnement Electromagnetique, University of Paris-Sud) on the storage ring DCI with an energy of $1.85 \mathrm{GeV}$ and a mean intensity of 300-200 mA. The measurements were carried out at both copper and manganese K-edges in the transmission mode on the EXAFS III spectrometer equipped with a two-crystal monochromator (Si 311, $0.5 \mathrm{~mm}$ entrance slit for both XANES and EXAFS). The monochromator was slightly detuned to ensure harmonics reflection. Reduced pressure air-filled ionization chambers were used to measure the flux intensity before and after the insertion of the sample. The spectra were recorded at $40 \mathrm{~K}$ in a helium cryostat designed for X-ray absorption spectroscopy. A detailed description of the operating mode is given in reference 31 .

The XANES and standard EXAFS data analyses were performed with the GALAAD and EXAFS pour le MAC programs $^{32}$ in the framework of the single-scattering approach by following a well-known procedure described elsewhere. $^{31}$

\section{Results and Discussion}

\section{Structural characterization}

The lack of single crystals of $\mathbf{1 - 3}$ and their poor crystallinity precluded us to get structural information by the common X-ray diffraction techniques. Therefore, we have decided to study the XANES and EXAFS spectra of 1-3.

Figure 1 displays normalized XANES spectra for 1-3 both at the copper (a) and manganese (b) K-edges. The three spectra at the copper K-edge (Figure 1a) are almost superimposable in their shapes and transition energies, suggesting strong similarities in the geometry about the copper ion for 1-3. The comparison between the XANES spectra of $\mathbf{3}$ at the copper K-edge and the copper(II) precursor monomer $\left[\mathrm{Cu}(\mathrm{Hdmg})_{2}\right]$ (Figure 1c) reveals that the two edges are practically identical. 
(a)

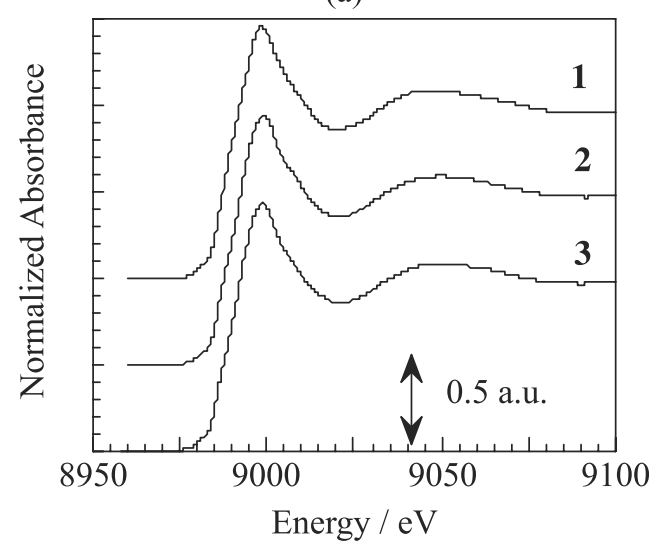

(c)

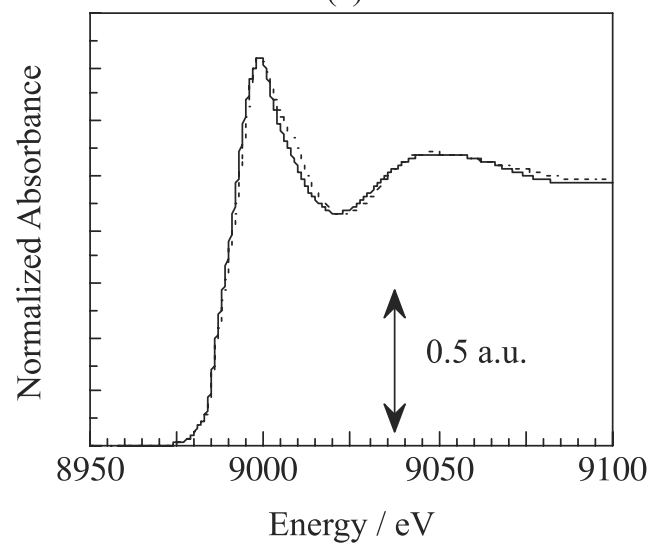

(b)

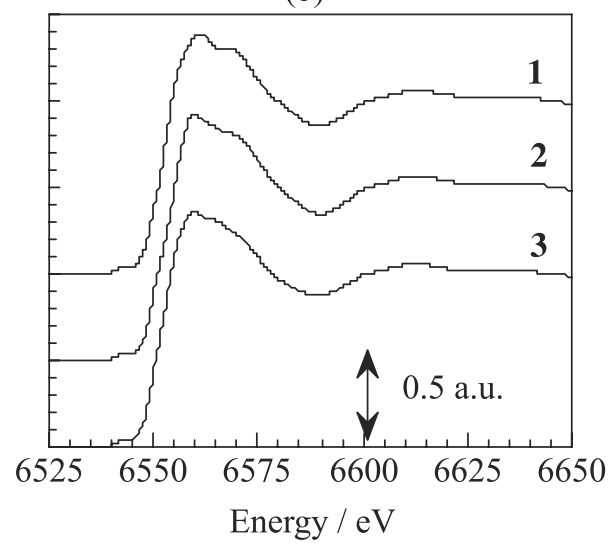

(d)

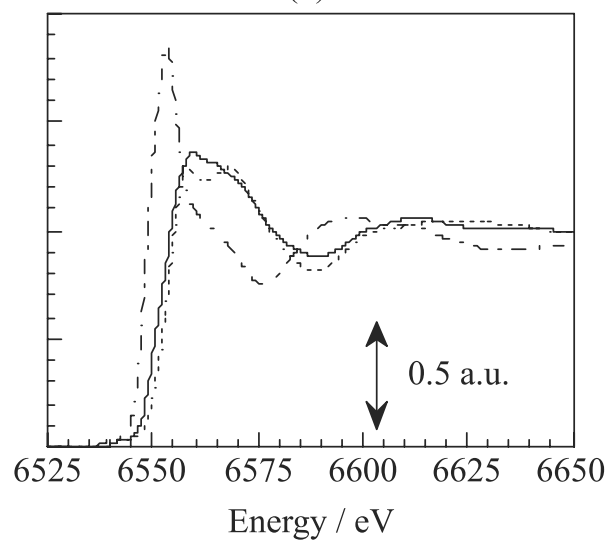

Figure 1. Normalized XANES spectra at copper (a) and manganese (b) K-edges for 1-3 at $40 \mathrm{~K}$. Comparison of normalized XANES spectra at copper (c)

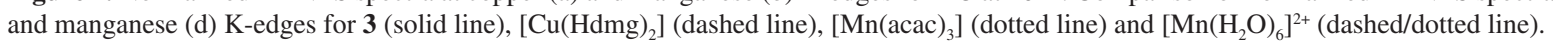

Thus, the copper coordination sphere has remained unchanged upon chain formation. The edges for 1-3 are typical of copper(II) complexes with a very weak $1 \mathrm{~s} \rightarrow 3 \mathrm{~d}$ pre-edge feature, as expected for complexes with a first coordination sphere close to an inversion center, where such transitions are symmetry forbidden. ${ }^{33}$ The most important feature of the spectra at the copper edge is that the low-energy side of the edge exhibits the characteristic shoulder of copper(II) in an elongated tetragonal surrounding. ${ }^{34}$ The three spectra at the manganese K-edge (Figure 1b) show also a very weak $1 \mathrm{~s} \rightarrow 3 \mathrm{~d}$ pre-edge feature indicating that manganese metal ion is located on a (quasi) inversion center. ${ }^{33}$ The absorption edges are centered at $c a .6560 \mathrm{eV}$. Figure 1d displays the comparison among XANES spectra of $\mathbf{3}$, $\left[\mathrm{Mn}^{\mathrm{III}}(\mathrm{acac})_{3}\right]($ Hacac $=$ acetylacetone $)$ and an aqueous solution of manganese(II) nitrate at the manganese K-edge. It has been shown that the edge shifts to higher energies as the oxidation state increases..$^{35}$ For aqueous manganese(II) the absorption edge appears at $6548 \mathrm{eV}$ and in manganese(III)-acetylacetonate the edge is centered at ca. $6559 \mathrm{eV}$, supporting clearly the presence of a trivalent oxidation state in the 1-3 family. The top of the edge, which is afforded by the symmetry-allowed $1 \mathrm{~s} \rightarrow 4 \mathrm{p}$ transitions, is characterized by an absorbance that is not large compared to the atomic absorption (from 1.42 in $\mathbf{1}$ to 1.23 in 3) and an important width, including the shoulder in the high-energy side of the edge. Both features are at variance with the sharp white line (>2) observed for $\left[\mathrm{Mn}\left(\mathrm{H}_{2} \mathrm{O}\right)_{6}\right]^{2+}$ where all the $\mathrm{Mn}-\mathrm{O}$ distances are equivalent in the octahedron, indicating that the environment in compounds 1-3 is distorted. ${ }^{36}$ This situation is usually observed for distorted octahedral complexes, where a large distribution of distances splits the empty $p$ molecular levels. ${ }^{37}$ It is also likely that multiple scattering by the carbon atoms of the ligands is also operating in this energy range. ${ }^{38}$ The two views, however, converge to the same situation, i.e., a distortion of the octahedral environment that decreases when passing from $\mathbf{1}$ to $\mathbf{3}$. This is reflected by the fact that in $\mathbf{3}$ the main edge transitions are worst resolved and the intensity of the top of the edge is minimal.

The $k$-space experimental EXAFS spectra for $\mathbf{1}$, at both copper (a) and manganese (b) K-edges, and the corresponding Fourier transforms are given in Figure 2 
(Figures S1 and S2 for compounds $\mathbf{2}$ and $\mathbf{3}$, respectively, as Supplementary Information, SI). Manganese and copper absorption edge data were collected to $k=15 \AA^{-1}$, resulting in good resolution of peaks in the Fourier transforms. The strong similarity of the experimental spectra corresponding to 1-3 at both copper and manganese K-edges allows us to assume that the local structure of the copper and manganese ions are nearly the same for all of them, the slight differences being attributed to the presence of different substituents. In particular, the amplitudes of the EXAFS oscillations appear almost unchanged. Thus, there is the same number of nearest neighbours around each metal ion in all three compounds. Each atomic shell surrounding at the metal ion is represented by a peak on the Fourier transforms. Both copper and manganese spectra comprise four main peaks. In the case of the copper K-edge (Figure 2a right), the first one corresponds mainly to four nitrogen atoms from two oxime ligands, the second and the third ones to carbon and oxygen atoms from these ligands and the fourth one to the $\mathrm{Cu}-\mathrm{Mn}$ interaction. At the manganese K-edge (Figure $2 b$ ), the first peak corresponds mainly to four oxygen atoms of four distinct oxime ligands which belong

(a)

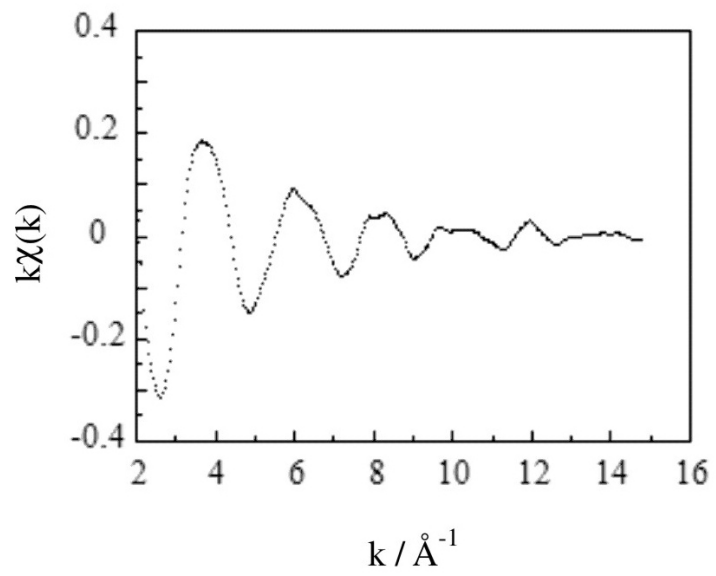

(b)

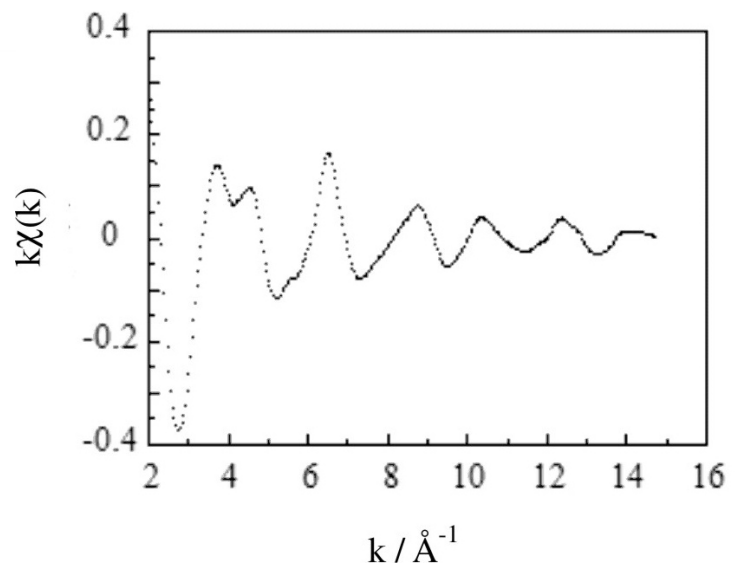

to the coordination sphere of the metal ion. The number and postulated nature of neighbours, the absorber-neighbours distances, the Debye-Waller factors and other parameters resulting from quantitative analyses of EXAFS data for compounds 1-3 at both manganese and copper K-edges are available in Table 1 and the calculated spectra compared to the experimental ones in Figure S3 for 1-3 (see SI). These data confirm the above qualitative discussion. The copper(II) ions are surrounded by six neighbours (nitrogen and/or oxygen) atoms with four short $\mathrm{Cu}-\mathrm{N}$ (oxime) average distances in the range 1.99-2.00 $\AA$ and two somewhat longer $\mathrm{Cu}-\mathrm{O}$ (water) bonds at 2.13(7) and 2.29(22) (1), 2.13(6) and 2.31(35) (2) 2.10(6) and 2.28(17) $\AA$ (3), respectively. The manganese(III) ions exhibit an environment of six oxygen atoms with four short $\mathrm{M}-\mathrm{O}$ (oxime) distances in the range 1.95-1.96 $\AA$ and two somewhat longer $\mathrm{Mn}-\mathrm{O}$ (carboxylate) at 2.10(2) and 2.30(4) (1), 2.13(7) and 2.33(5) (2) 2.15(10) and 2.31(13) $\AA$ (3), respectively. The shortest values of the $\mathrm{Cu} \cdots \mathrm{Mn}$ separation are 3.68(20) (1 and 2) and $3.70(16) \AA(3)$. These values are in agreement with the occurrence of oximato-bridged bimetallic chains, as shown in Scheme 3. ${ }^{27,39}$
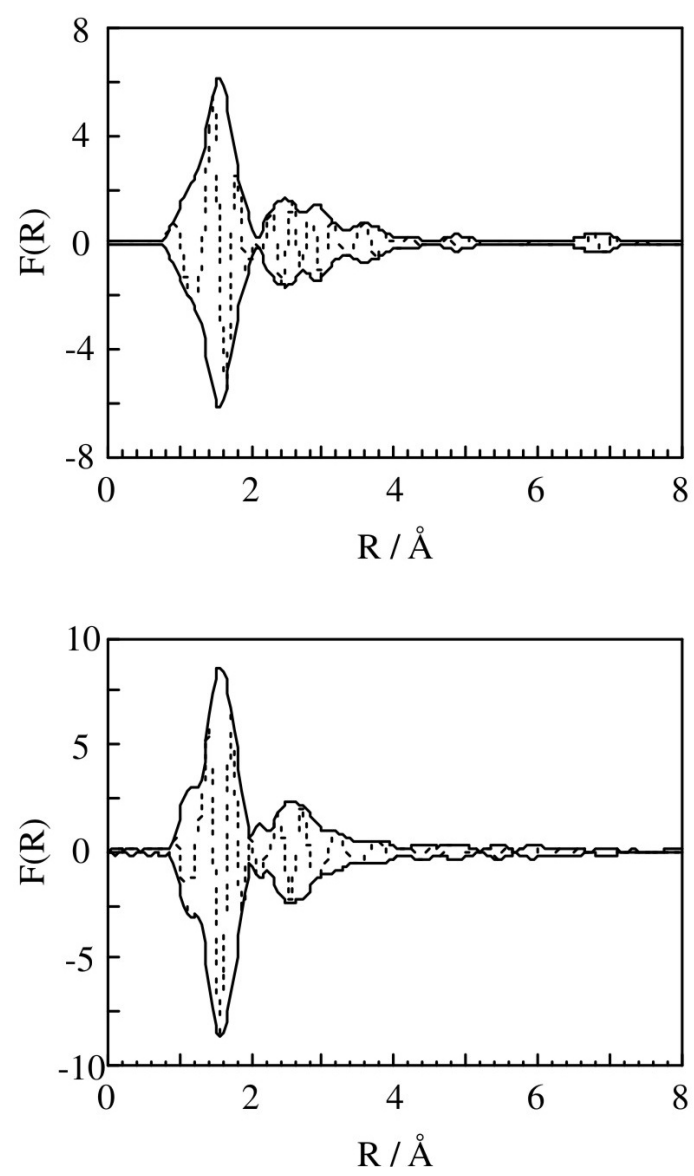

Figure 2. $k$-space experimental EXAFS spectra $\mathrm{k} \chi(\mathrm{k}) v s . \mathrm{k}$ (left) and the corresponding Fourier transforms (right) at the copper (a) and manganese (b) K-edges for 1 at $40 \mathrm{~K}$. 
Table 1. Structural results for 1-3 obtained by fitting of the EXAFS data ${ }^{\mathrm{a}}$

\begin{tabular}{|c|c|c|c|c|c|c|}
\hline & Compound & $\mathrm{N}^{\mathrm{b}}$ & $\mathrm{R}^{\mathrm{c}} / \AA$ & $\sigma^{\mathrm{d}} / \AA$ & $\Gamma^{\mathrm{e}} / \AA$ & $\% \rho^{t}$ \\
\hline \multicolumn{7}{|c|}{ Cu K-edge } \\
\hline \multirow[t]{6}{*}{1} & $\mathrm{Cu}-\mathrm{N}$ & 4 & $2.00(2)$ & 0.05 & 1.4 & 3.8 \\
\hline & $\mathrm{Cu}-\mathrm{O}$ & 1 & $2.13(7)$ & 0.03 & 1.4 & \\
\hline & $\mathrm{Cu}-\mathrm{O}$ & 1 & $2.29(22)$ & 0.08 & 1.4 & \\
\hline & $\mathrm{Cu}-\mathrm{C}$ & 4 & $2.82(5)$ & 0.03 & 1.4 & \\
\hline & $\mathrm{Cu}-\mathrm{O}$ & 4 & $2.97(13)$ & 0.09 & 1.4 & \\
\hline & $\mathrm{Cu}-\mathrm{Mn}$ & 2 & $3.68(20)$ & 0.10 & 1.4 & \\
\hline \multirow[t]{6}{*}{2} & $\mathrm{Cu}-\mathrm{N}$ & 4 & $2.00(2)$ & 0.04 & 1.3 & 2.9 \\
\hline & $\mathrm{Cu}-\mathrm{O}$ & 1 & $2.13(6)$ & 0.03 & 1.3 & \\
\hline & $\mathrm{Cu}-\mathrm{O}$ & 1 & $2.31(35)$ & 0.10 & 1.3 & \\
\hline & $\mathrm{Cu}-\mathrm{C}$ & 4 & $2.835(8)$ & 0.02 & 1.3 & \\
\hline & $\mathrm{Cu}-\mathrm{O}$ & 4 & $3.00(2)$ & 0.09 & 1.3 & \\
\hline & $\mathrm{Cu}-\mathrm{Mn}$ & 2 & $3.68(2)$ & 0.08 & 1.3 & \\
\hline \multirow[t]{6}{*}{3} & $\mathrm{Cu}-\mathrm{N}$ & 4 & $1.99(2)$ & 0.04 & 1.2 & 2.8 \\
\hline & $\mathrm{Cu}-\mathrm{O}$ & 1 & $2.10(6)$ & 0.02 & 1.2 & \\
\hline & $\mathrm{Cu}-\mathrm{O}$ & 1 & $2.28(17)$ & 0.10 & 1.2 & \\
\hline & $\mathrm{Cu}-\mathrm{C}$ & 4 & $2.83(4)$ & 0.03 & 1.2 & \\
\hline & $\mathrm{Cu}-\mathrm{O}$ & 4 & $2.97(8)$ & 0.08 & 1.2 & \\
\hline & $\mathrm{Cu}-\mathrm{Mn}$ & 2 & $3.70(16)$ & 0.10 & 1.2 & \\
\hline \multicolumn{7}{|c|}{ Mn K-edge } \\
\hline \multirow[t]{3}{*}{1} & $\mathrm{Mn}-\mathrm{O}$ & 4 & $1.95(0)$ & 0.03 & 1.5 & 0.4 \\
\hline & $\mathrm{Mn}-\mathrm{O}$ & 1 & $2.10(2)$ & 0.05 & 1.5 & \\
\hline & $\mathrm{Mn}-\mathrm{O}$ & 1 & $2.30(4)$ & 0.07 & 1.5 & \\
\hline \multirow[t]{3}{*}{2} & $\mathrm{Mn}-\mathrm{O}$ & 4 & $1.95(0)$ & 0.05 & 1.4 & 1.7 \\
\hline & $\mathrm{Mn}-\mathrm{O}$ & 1 & $2.13(7)$ & 0.11 & 1.4 & \\
\hline & $\mathrm{Mn}-\mathrm{O}$ & 1 & $2.33(5)$ & 0.08 & 1.4 & \\
\hline \multirow[t]{3}{*}{3} & $\mathrm{Mn}-\mathrm{O}$ & 4 & $1.96(2)$ & 0.05 & 1.4 & 0.6 \\
\hline & $\mathrm{Mn}-\mathrm{O}$ & 1 & $2.15(10)$ & 0.01 & 1.4 & \\
\hline & $\mathrm{Mn}-\mathrm{O}$ & 1 & $2.31(13)$ & 0.03 & 1.4 & \\
\hline
\end{tabular}

aThe fits were done using the theoretical amplitudes and phases of McKale et al. $;{ }^{40}$ bumber of atoms $N$ was allowed to vary during the fitting procedure; ${ }^{c} R$ is the distance from the copper or manganese absorber. Errors are given in parentheses; ${ }^{\mathrm{d}} \sigma$ is the Debye-Waller coefficient; ${ }^{e}$ mean-electron-free path $\lambda$ was chosen as $\lambda(\mathrm{k})=(1 / \Gamma)\left[(\eta / \mathrm{k})^{4}+\mathrm{k}\right]$ with $\eta=3.1$ and $\Gamma$ was allowed to vary; ${ }^{\mathrm{f}} \rho$ is the residual factor defined as $\sum\left(\mathrm{k} \chi \exp -\mathrm{k} \chi_{\mathrm{th}}\right)^{2} / \sum \mathrm{k} \chi_{\mathrm{epx}}^{2}$.

\section{Magnetic properties}

The temperature dependence of $\chi_{\mathrm{M}} T$ product for $\mathbf{1}$ $\left(\chi_{\mathrm{M}}\right.$ is the magnetic susceptibility per $\mathrm{Cu}^{\mathrm{II}}-\mathrm{Mn}^{\mathrm{III}}$ pair) is shown in Figure 3. An analogous behavior is observed for $\mathbf{2}$ (Figure S4) and $\mathbf{3}$ (Figure S5). At room temperature, $\chi_{\mathrm{M}} T$ for $\mathbf{1 - 3}$ varies in the range $4.31-4.53 \mathrm{~cm}^{3} \mathrm{~mol}^{-1} \mathrm{~K}$ $\left(\mu_{\text {eff }} c a .5 .96 \mu_{\mathrm{B}}\right)$, a value which is higher than the spinonly value for the magnetically non-interacting $\mathrm{Cu}^{\mathrm{II}}-\mathrm{Mn}^{\mathrm{III}}$ pair $\left(\mu_{\text {eff }}=5.20 \mu_{\mathrm{B}}\right)$ and very close to that expected for a sextuplet spin state $\left(\mu_{\text {eff }}=5.92 \mu_{\mathrm{B}}\right.$ with $\left.g=2.0\right)$. Upon cooling down, $\chi_{\mathrm{M}} T$ continuously increases up to 32.0 (1), $21.4(2)$ and $23.0 \mathrm{~cm}^{3} \mathrm{~mol}^{-1} \mathrm{~K}(3)$ at $10.0(\mathbf{1}), 12.5(\mathbf{2})$ and $14.0 \mathrm{~K}(3)$. This behavior is indicative of a strong intrachain ferromagnetic coupling between copper(II) and

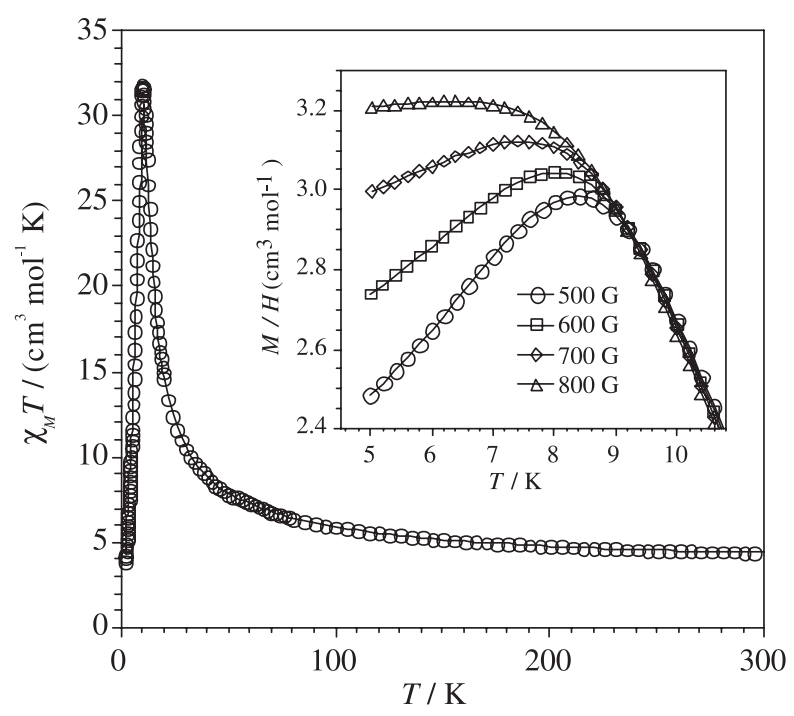

Figure 3. Temperature dependence of the $\chi_{\mathrm{M}} T$ product for $\mathbf{1}$ at $500 \mathrm{G}$ : (o) experimental; (-) calculated curve as discussed in the text. The inset shows the field dependence of $M / H$ of $\mathbf{1}$ in the low temperature region (the solid lines are eye-guides).

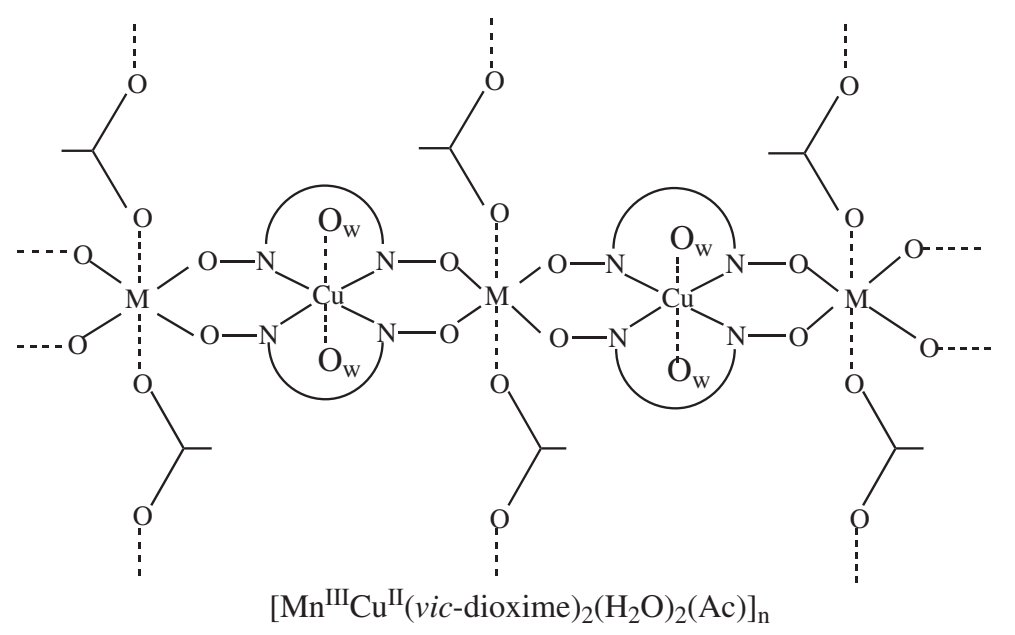

Scheme 3. 
manganese(III) ions. At lower temperatures, $\chi_{\mathrm{M}} T$ decreases sharply and a maximum of $\chi_{\mathrm{M}}$ occurs at $8.5(\mathbf{1}), 11.0(\mathbf{2})$ and $12.0 \mathrm{~K}(\mathbf{3})$. This maximum is field dependent and disappears for applied dc fields larger than 800 (1), 3000 (2) and $4500 \mathrm{G} \mathrm{(3)}$ [see insets of Figures 3 (1), S4 (2) and S5 (3)]. The presence of these maxima in the $\chi_{\mathrm{M}} v s . T$ plots for 1-3 is a clear indication that an interchain antiferromagnetic coupling is involved in the three compounds.

Having in mind the structural information obtained by the analysis of the EXAFS data for this family (Scheme 3), a carboxylate bridge between the manganese(III) ions would account for the weak interchain antiferromagnetic coupling, the structure of 1-3 being considered as two-dimensiona1 with a large intrachain ferromagnetic coupling between the copper(II) and manganese(III) ions through the double oximato bridge. Consequently, we have treated the magnetic data of 1-3 as a "chain of chains". In this approach, at a given temperature, we associated to the bridged oximato-bridged copper(II)-manganese(III) chain an effective total spin, $S_{\text {eff }}$, which can be calculated through equation 1 :

$S_{\text {eff }}\left(S_{\text {eff }}+1\right)=2 \chi_{\mathrm{fc}} T$

where $\chi_{\mathrm{fc}}$ is the susceptibility calculated for this ferromagnetic chain from the classic-quantic spin model. ${ }^{41}$ For $T<30 \mathrm{~K}$, the values of $\chi_{\mathrm{fc}} T$ are so large that $S_{\text {eff }}$ takes values large enough $\left(S_{\text {eff }}>5\right)$ to be treated as a classical spin. Then, the magnetic susceptibility for the two-dimensional network of 1-3 can be calculated from the classical spin model for antiferromagnetic linear chains with total spin $S_{\text {eff }}{ }^{42,43}$ The best-fit parameters for 1-3 are grouped in Table 2 with values for the intra- $(J)$ and interchain $(j)$ magnetic couplings varying in the ranges +52.5 to $+49.1 \mathrm{~cm}^{-1}$ and -0.070 to $-0.078 \mathrm{~cm}^{-1}$, respectively. The calculated curves for all three compounds reproduce reasonably well the magnetic data in the whole temperature range investigated in spite of our crude model for the interacting spins.

The values of the intrachain ferromagnetic coupling in 1-3 are very close and in agreement with the structural similarity of the double-oximato bridge between copper(II) and manganese(III) from the EXAFS analysis in this family (values for the shortest copper(II)-manganese(III) separation in 1-3 of $c a .3 .70 \AA$ ). This intrachain ferromagnetic coupling can be understood on the basis of the symmetry of the interacting magnetic orbitals (that is, the molecular orbitals which define the unpaired electrons on each spin carrier). The unpaired electron of the copper(II) ion in 1-3 is defined by a $\mathrm{d}_{x^{2}-y^{2}}$ type orbital (the $x$ and $y$ axes corresponding roughly to the basal $\mathrm{Cu}-\mathrm{N}$ (oximato) bonds) and, as far as the elongated octahedral high-spin manganese(III) center is concerned, its four unpaired electrons are defined by the electronic configuration $\left(\mathrm{d}_{\mathrm{xz}}, \mathrm{d}_{\mathrm{yz}}\right)^{2}$, $\left(\mathrm{d}_{\mathrm{xy}}\right)^{1},\left(\mathrm{~d}_{z^{2}}\right)^{1}\left(\mathrm{~d}_{\left.\mathrm{x}^{2}-\mathrm{y}^{2}\right)^{0}}\right.$ in order of increasing energy. Thus, the magnetic orbitals of the manganese(III) center are strictly orthogonal to the $\mathrm{d}_{x^{2}-y^{2}}$ orbital of the copper(II), resulting in a parallel spin alignment (Scheme 4). In the case where the manganese(III) is replaced by a high-spin iron(III), the additional electron occupies the upper $\mathrm{d}_{x^{2}-y^{2}}$ orbital and the strict orthogonality vanishes because of the net overlap between the two $d_{x^{2}-y^{2}}$ orbitals, the magnetic coupling becoming antiferromagnetic. Such a case is represented by the double oximato-bridged $\mathrm{Cu}^{\mathrm{II}}-\mathrm{Fe}^{\mathrm{III}}$ one-dimensional compound $\left[\mathrm{FeCu}(\mathrm{dmg})_{2}\left(\mathrm{CH}_{3} \mathrm{COO}\right)\left(\mathrm{H}_{2} \mathrm{O}\right)_{2}\right]$, where the intrachain magnetic coupling is $J=-48 \mathrm{~cm}^{-1}$. 4

The coexistence of ferro and antiferromagnetic interactions in 1-3 is confirmed by the shape of the corresponding magnetization $(M) v s . H$ plots at $2.0 \mathrm{~K}$ : sigmoidal shapes and sharp increases of the magnetization with the increasing field, the values of $M$ at $5 T$ (the maximum dc field in our device) being somewhat below but close to $5.0 \mu_{\mathrm{B}}$, the theoretical value of the saturation magnetization for a spin $S=S_{\mathrm{Mn}}+S_{\mathrm{Cu}}=5 / 2$ per $\mathrm{Mn}^{\mathrm{III}} \mathrm{Cu}^{\mathrm{II}}$ unit [Figures 4 (1), S6 (2) and S7 (3)]. At low temperatures, 1-3 exhibit quite peculiar magnetic properties which can be described as a metamagnetic-like behavior. ${ }^{45}$ As shown in the insets of Figures 3 (1), S4 (2) and S5 (3), maxima of the magnetic susceptibility occur at $T_{\mathrm{c}}=8.5(\mathbf{1}), 11.0(\mathbf{2})$ and $12.0 \mathrm{~K}(\mathbf{3})$ which broaden as the dc applied field increases and disappear for $H_{\mathrm{c}} \geq 800$ (1), 3000 (2) and $4500 \mathrm{G}(3) \cdot{ }^{45,46}$ The confirmation of this metamagnetic-like behavior is provided by the isotherms of the magnetization for some temperatures above and below the corresponding

Table 2. Magnetic parameters for $\mathbf{1 - 3 ^ { a }}$

\begin{tabular}{lccccccccc}
\hline Compound & $J^{\mathrm{a} / \mathrm{cm}^{-1}}$ & $j^{\mathrm{b} / \mathrm{cm}^{-1}}$ & $g_{\mathrm{Cu}}$ & $g_{\mathrm{Mn}}$ & $T_{\mathrm{c}}^{\mathrm{c}} / \mathrm{K}$ & $H_{\mathrm{c}} \mathrm{d} / \mathrm{G}$ & $H_{\text {coer }} / \mathrm{G}$ & $\tau_{\mathrm{o}}^{\mathrm{f}} / \mathrm{s}$ & $E_{\mathrm{a}}^{\mathrm{g}} / \mathrm{cm}^{-1}$ \\
\hline $\mathbf{1}$ & +52.5 & -0.070 & 2.12 & 1.99 & 8.5 & 800 & 550 & $6.1 \times 10^{-12}$ & 35.8 \\
$\mathbf{2}$ & +49.1 & -0.075 & 2.10 & 1.99 & 11.0 & 3000 & 100 & $3.1 \times 10^{-12}$ & 32.7 \\
$\mathbf{3}$ & +52.1 & -0.078 & 2.21 & 2.00 & 12.0 & 4500 & 120 & $1.3 \times 10^{-12}$ & 35.5 \\
\hline
\end{tabular}

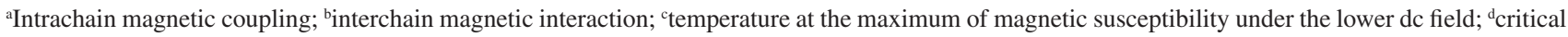
magnetic field; ${ }^{\mathrm{e}}$ coercive field; ${ }^{\mathrm{f}}$ pre-exponential factor in the Arrhenius law; ${ }^{\mathrm{g}}$ activation energy to reverse the magnetization direction. 


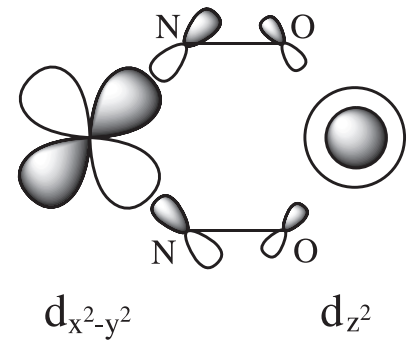

$\mathrm{d}_{\mathrm{x}^{2}-\mathrm{y}^{2}}$

$\mathrm{d}_{\mathrm{z}^{2}}$

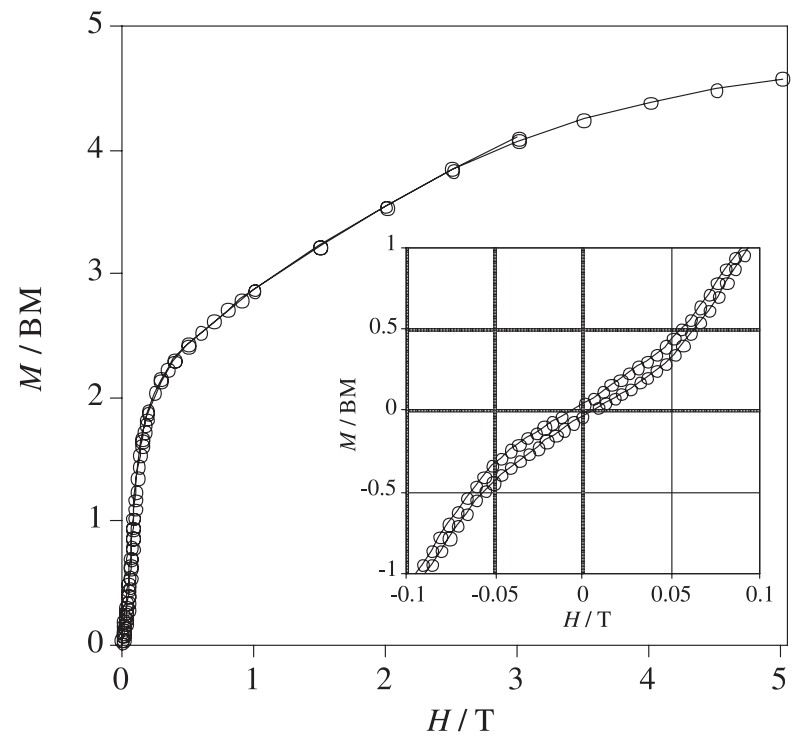

Figure 4. Magnetization $v s$. $H$ plot for 1 at $2.0 \mathrm{~K}$ : (o) experimental; (-) eyeguide. The insert shows the hysteresis loop of $\mathbf{1}$ at very low magnetic fields.

$T_{\mathrm{c}}$ values which are shown in Figures 5 (1), S8 (2) and S9 (3). The value of the applied field for the crossing point of the isotherms in these figures is the critical field $\left(H_{\mathrm{c}}\right)$, that is, the applied field which induces the transition when $T \rightarrow 0 \mathrm{~K}$. It is interesting to note that the values of the effective interchain antiferromagnetic coupling in 1-3 (j) follow the observed trend of $T_{\mathrm{c}}, T_{\mathrm{c}}(\mathbf{1})<T_{\mathrm{c}}(\mathbf{2})<T_{\mathrm{c}}$ (3) and $H_{\mathrm{c}}, H_{\mathrm{c}}(\mathbf{1})<H_{\mathrm{c}}(\mathbf{2})<H_{\mathrm{c}}(\mathbf{3})$.

Interestingly, hysteresis loops corresponding to soft magnets with values of the coercive field of 550 (1), 100 (2) and $120 \mathrm{G}(\mathbf{3})$ occur in the low field region of the $M v s . H$ plots at $2.0 \mathrm{~K}$ [insets of Figures 4 (1), S6 (2) and S7 (3)]. A weak canting within the magnetic planes of 1-3 would be responsible for the hysteresis loops under very low applied dc fields. However, we have not observed any peak in the heat capacity measurements of 1-3 in the temperature range 2.0-20 K, indicating that no magnetic ordering occurs. So, the maxima observed in the magnetic susceptibility curves do not correspond to an antiferromagnetic ordering. We think they correspond to an antiferromagnetic interaction between chains within the planes but not between planes (no 3D ordering). The weak spin canting, responsible for

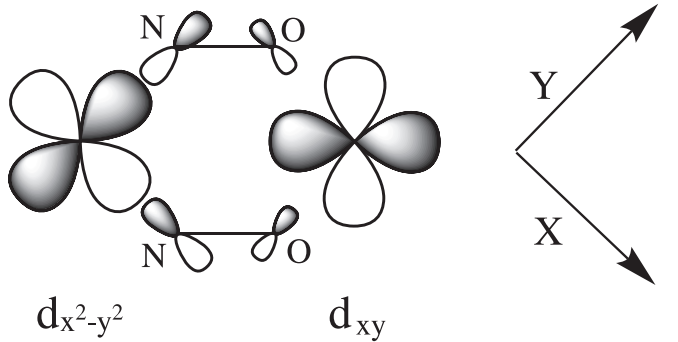

Scheme 4.

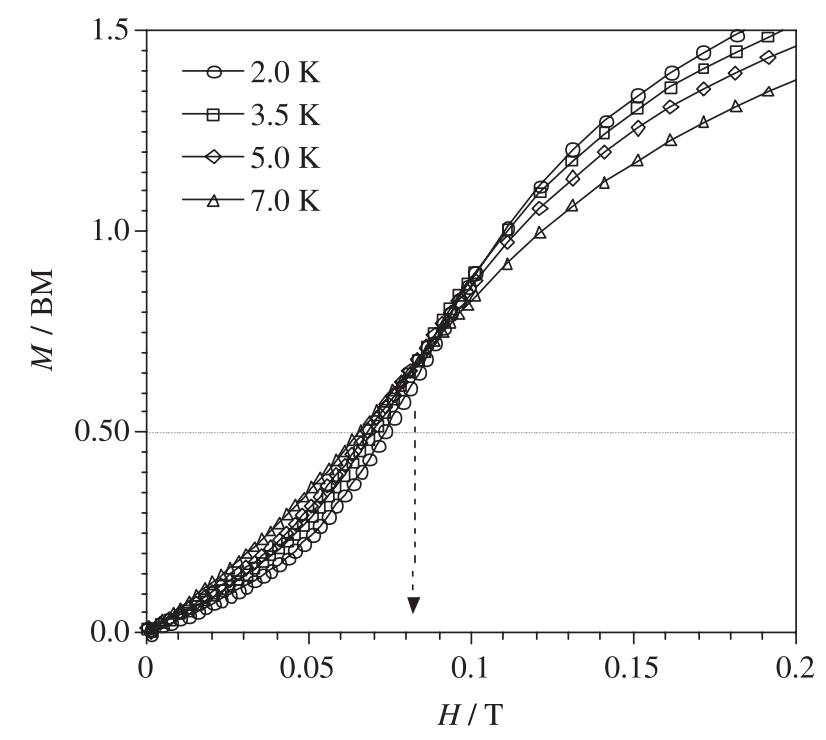

Figure 5. Magnetization isotherms for $\mathbf{1}$ at the indicated temperatures.

the hysteresis loop, must be a phenomenon within the plane that could most likely be due to blocking effects of small regions. Interestingly, ac susceptibility measurements of 1-3 show evidence of slow magnetic relaxation effects at very low temperatures as found for SCMs [Figures 6 (1), S10 (2) and S11 (3)]. ${ }^{13-17}$ The out-of-phase magnetic susceptibility $\left(\chi_{\mathrm{M}}{ }^{\prime}\right)$ becomes non-zero for temperatures below ca. $4.0 \mathrm{~K}$ and exhibits frequency-dependent maxima whose intensities decrease with decreasing frequency. These frequency-dependent ac signals are in agreement with the absence of magnetic ordering and they may be attributed to a phenomenon of low dimensionality such as a plane (2D). The fact that the extrapolated value of the $\chi_{\mathrm{M}}$ at $T=0$ is $c a .2 / 3$ its value at the temperature in which it is a maximum (Figure 6 for $\mathbf{1}$ ) provides an additional support to this low magnetic dimensionality.

The relaxation time $\tau$ for $\mathbf{1 - 3}$ can be calculated from the maxima of $\chi_{\mathrm{M}}$ " at a given frequency $\mathrm{v}$, whereby it is assumed that the switching of the oscillating ac field matches the relaxation rate of the magnetization $(1 / \tau=2 \pi v)$. The calculated $\tau$ values at $T_{\max }$ follow the Arrhenius law characteristic of a thermally activated mechanism $\left(\tau=\tau_{\mathrm{o}} \exp \left(E_{\mathrm{a}} / k_{\mathrm{B}} T\right)\right.$ [inset of Figures 7 (1), S12 (2) and S13 (3)] with values of 


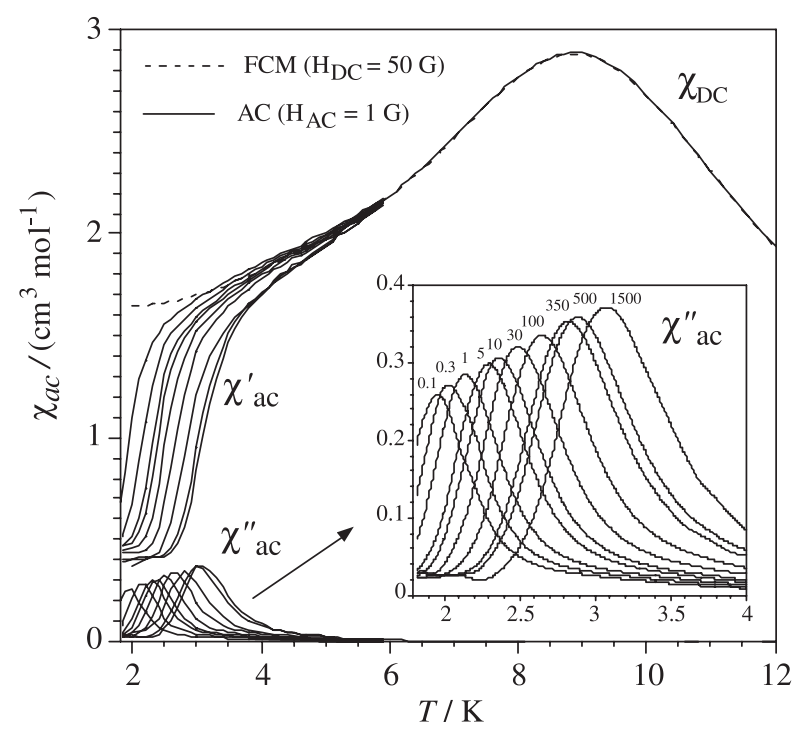

Figure 6. Field-cooled magnetization of 1 under an applied dc field of $50 \mathrm{G}$ (dashed line) and temperature dependence of the in-phase $\left(\chi_{\mathrm{M}}{ }^{\prime}\right)$ and out-of-phase $\left(\chi_{\mathrm{M}}{ }^{\prime}\right)$ ac signals in zero applied static field and under $1 \mathrm{G}$ oscillating field at different frequencies (solid lines). The inset shows the frequency dependence of $\chi_{\mathrm{M}}$ " at very low temperatures.

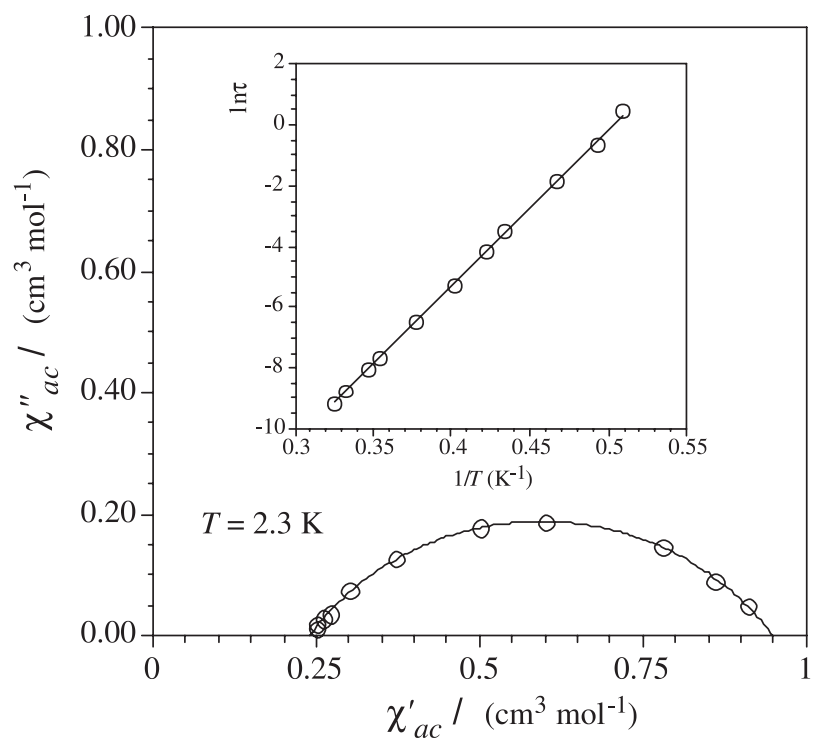

Figure 7. Cole-Cole plot at $2.3 \mathrm{~K}$ for $\mathbf{1}$. The inset shows the Arrhenius plot for $\mathbf{1}$. The solid lines are the best-fit curves (see text).

activation energies $\left(E_{\mathrm{a}}\right)$ and pre-exponential factors $\left(\tau_{\mathrm{o}}\right)$ that are listed in Table 2. As expected, the larger the intrachain magnetic coupling, the greater the energy barrier to reverse the magnetization direction. However, the values must be considered with caution because of the very narrow temperature range available for 1-3. The $\chi_{\mathrm{M}}$ " vs. $\chi_{\mathrm{M}}$ ' plot at $2.3 \mathrm{~K}$ for 1 (Cole-Cole plot) ${ }^{47}$ in the frequency range 1-1500 Hz gives a semicircle (Figure 7). The least-squares fit of the experimental data through the Cole-Cole expression, $\chi=\chi_{S}+\left(\chi_{T}-\chi_{S}\right) /(1+i \omega \tau)$, gave a value for the $\alpha$ parameter of 0.38 ( $\alpha=0$ for an ideal Debye model with a single relaxation time). ${ }^{47,48}$ The adiabatic $\left(\chi_{S}\right)$ and isothermal $\left(\chi_{T}\right)$ susceptibilities for 1 are 0.24 and $0.95 \mathrm{~cm}^{3} \mathrm{~mol}^{-1}$. The relatively large value of $\alpha$ for 1 is indicative of the occurrence of significant intraplane interactions in $\mathbf{1}$, in agreement with the decrease of the intensity of the out-of-phase ac signals when the frequency decreases. As far as we know, slow magnetic relaxation for a plane (2D) has been rarely observed and more studies are needed to get deeper insights on these interesting magnetic systems. ${ }^{49}$

\section{Conclusions}

A new family of doubly oximato-bridged heterobimetallic $\mathrm{Cu}^{\mathrm{II}}-\mathrm{Mn}^{\mathrm{III}}$ chains with a relatively large intrachain ferromagnetic coupling has been obtained by using the "complex as ligand" strategy. This ferromagnetic interaction is due to the strict orthogonality between the interacting magnetic orbitals at the copper(II) and manganese(III) centers (one and four respectively). The metamagnetic-like behavior observed for this system is caused by weak interchain antiferromagnetic interactions that are developed within a 2D arrangement and coexist with weak spin-canting. This spin-canting in the magnetically isolated planes would account for the observed slow magnetic-relaxation.

\section{Supplementary Information}

Supplementary data concerning EXAFS spectra (Figures S1-S3) and magnetic measurements (Figures S4-S13) are available free of charge at http://jbcs.sbq.org.br as pdf file.

\section{Acknowledgments}

We would like to express our gratitude to Dr. F. Villain for her help in the use of the EXAFS 3 spectrometer and cryogenic device, and to Prof. Dr. A. Michalowicz (LURE) for his help in the use of the FEFF program and fruitful discussions. Financial support from the Ministerio Español de Ciencia y Tecnología through the projects CTQ201015364 and Consolider Ingenio CSD-2007-00010 (Molecular Nanoscience) is gratefully acknowledged. J. F. S. also thanks the Generalitat Valenciana for a doctoral grant.

\section{References}

1. Tschugaeff, L.; Chem. Ber. 1890, 23, 1.

2. Kukushkin, V. Y.; Pombeiro, A. J. L.; Coord. Chem. Rev. 1999, 181, 147 and references therein.

3. Chaudhuri, P.; Coord. Chem. Rev. 2003, 243, 143 and references therein. 
4. Bertrand, J. A.; Smith, J. H.; Eller, P. G.; Inorg. Chem. 1974, 13, 1649.

5. Luneau, D.; Oshio, H.; Okawa, H.; Koikawa, M.; Kida, S.; Bull. Chem. Soc. Jpn. 1990, 63, 2212.

6. Ruiz, R.; Sanz, J.; Cervera, B.; Lloret, F.; Julve, M.; Bois, C.; Faus, J.; Muñoz, M. C.; J. Chem. Soc., Dalton Trans. 1993, 1623; Ruiz, R.; Lloret, F.; Julve, M.; Muñoz, M. C.; Bois, C.; Inorg. Chim. Acta 1994, 219, 179.

7. Chaudhuri, P.; Winter, M.; Flörke, U.; Haupt, H. J.; Inorg. Chim. Acta 1995, 232, 125.

8. Domínguez-Vera, J. M.; Colacio, E.; Escuer, A.; Klinga, M.; Kivekäs, R.; Romerosa, A.; Polyhedron 1997, 16, 281.

9. Maekawa, M.; Kitagawa, S.; Nakao, Y.; Sakamoto, S.; Yatani, A.; Mori, W.; Kashino, S.; Munakata, M.; Inorg. Chim. Acta 1999, 293, 20.

10. Song, Y.; Chen, X. T.; Zheng, C. G.; Zhu, D. R.; You, X. Z.; Transition Metal Chem. 2001, 26, 247.

11. Koumousi, E. S.; Raptopoulou, C. P.; Perlepes, S. P.; Escuer, A.; Stamatos, T. C.; Polyhedron 2010, 29, 204.

12. Kahn, O.; Brait, B.; J. Chem. Soc., Faraday T. 1976, 72, 268; Girerd, J. J.; Charlot, M. F.; Kahn, O.; Mol. Phys. 1977, 34, 1063; Kahn. O.; Charlot, M. F.; Nouv. J. Chim. 1980, 4, 567.

13. Lescouëzec, R.; Toma, L. M.; Vaissermann, J.; Verdaguer, M.; Delgado, F. S.; Ruiz-Pérez, C.; Lloret, F.; Julve, M.; Coord. Chem. Rev. 2005, 249, 2691.

14. Bogani, L.; Vindigni, A.; Sessoli, R.; Gatteschi, D.; J. Mater. Chem. 2008, 18, 4750.

15. Miyasaka, H.; Julve, M.; Yamashita, M.; Clérac, R.; Inorg. Chem. 2009, 48, 3420.

16. Sun, H. L.; Wang, Z. M.; Gao, S.; Coord. Chem. Rev. 2010 , $254,1081$.

17. Caneschi, A.; Gatteschi, D.; Lalioti, N.; Sangregorio, C.; Sessoli, R.; Vnturi, G.; Vindigni, A.; Rettori, A.; Pini, M. G.; Novak, M. A.; Angew. Chem., Int. Ed. 2001, 40, 1570; Caneschi, A.; Gatteschi, D.; Lalioti, N.; Sessoli, R.; Sorace, L.; Tangoulis, V.; Vindigni, A.; Chem. Eur. J. 2002, 8, 286; Bogani, L.; Sangregorio, C.; Sessoli, R.; Gatteschi, D.; Angew. Chem., Int. Ed. 2005, 44, 5817; Miyasaka, H.; Madanbashi, T.; Sugimoto, K.; Nakazawa, Y.; Wernsdorfer, W.; Sugiura, K. I.; Yamashita, M.; Coulon, C.; Clérac, R.; Chem. Eur. J. 2006, 12, 7028.

18. Glauber, R. J.; J. Math. Phys. 1963, 4, 294.

19. Clérac, R.; Miyasaka, H.; Yamashita, M.; Coulon, C.; J. Am. Chem. Soc. 2002, 124, 12837; Miyasaka, H.; Clérac, R.; Mizushima, K.; Sugiura, K. I.; Yamashita, M.; Wernsdorfer, W.; Coulon, C.; Inorg. Chem. 2003, 42, 8203; Miyasaka, H.; Nezu, T.; Sugimoto, K.; Sugiura, K. I.; Yamashita, M.; Clérac, R.; Chem. Eur. J. 2005, 11, 1592; Saitoh, A.; Miyasaka, H.; Yamashita, M.; Clérac, R.; J. Mater. Chem. 2007, 17, 2002; Miyasaka, H.; Saitoh, A.; Yamashita, M.; Clérac, R.; J. Chem. Soc., Dalton 2008, 2422; Miyasaka, H.; Takayama, K.; Saitoh, A.; Furukawa, S.; Yamashita, M.; Clérac, R.; Chem. Eur. J. 2010, 16, 3656.
20. Lescouëzec, R.; Vaissermann, J.; Ruiz-Pérez, C.; Lloret, F.; Carrasco, R.; Julve, M.; Verdaguer, M.; Dromzée, Y.; Gatteschi, D.; Wernsdorfer, W.; Angew. Chem., Int. Ed. 2003, 42, 1483; Toma, L. M.; Lescouëzec, R.; Lloret, F.; Julve, M.; Vaissermann, J.; Verdaguer, M.; Chem. Commun. 2003, 1850; Toma, L. M.; Delgado, F. S.; Ruiz-Pérez, C.; Carrasco, R.; Cano, J.; Lloret, F.; Julve, M.; Dalton Trans. 2004, 2836; Wang, S.; Zuo, J. L.; Gao, S.; Song, Y.; Zhou, H. C.; Zhang, Y. Z.; You, X. Z.; J. Am. Chem. Soc. 2004, 126, 8900; Ferbinteanu, M.; Miyasaka, H.; Wernsdorfer, W.; Nakata, K.; Sugiura, K. I.; Yamashita, M.; Coulon, C.; Clérac, R.; J. Am. Chem. Soc. 2005, 127, 3090; Toma, L. M.; Lescouëzec, R.; Pasán, J.; Ruiz-Pérez, C.; Vaissermann, J.; Cano, J.; Carrasco, R.; Wernsdorfer, W.; Lloret, F.; Julve, M.; J. Am. Chem. Soc. 2006, 128, 4842; Wen, H. R.; Wang, C. F.; Song, Y.; Gao, S.; Zuo, J. L.; You, X. Z.; Inorg. Chem. 2006, 45, 8942; Toma, L. M.; Lescouëzec, R.; Uriel, S.; Llusar, R.; Ruiz-Pérez, C.; Vaissermann, C.; Lloret, F.; Julve, M.; Dalton Trans. 2007, 3690; Choi, S. W.; Kwak, H. Y.; Yoon, J. H.; Kim, H. C.; Koh, E. K.; Hong, C. S.; Inorg. Chem. 2008, 47, 10214; Visinescu, D.; Madalan, A. M.; Andruh, M.; Duhayon, C.; Sutter, J. P.; Ungur, L.; Van der Heuvel, W.; Chibotaru, L. F.; Chem. Eur. J. 2009, 15, 11808; Guo, J. F.; Wang, X. T.; Wang, B. W.; Xu, G. C.; Gao, S.; Szeto, L.; Wong, W. T.; Wong, W. Y.; Lau, T. C.; Chem. Eur. J. 2010, 16, 3524.

21. Liu, T. F.; Fu, D.; Gao, S.; Zhang, Y. Z.; Sun, H. L.; Su, G.; Liu, Y. J.; J. Am. Chem. Soc. 2003, 125, 13976; Liu, X. T.; Wang, X. Y.; Zhang, W. X.; Cui, P.; Gao, S.; Adv. Mater. 2006, 18, 2852; Stamatos, T. C.; Abboud, K. A.; Wernsdorfer, W.; Christou, G. Inorg. Chem. 2009, 48, 807; Sun. H. L.; Wang, Z. M.; Gao, S.; Chem. Eur. J. 2009, 15, 1757.

22. Coronado, E.; Galán-Mascarós, J. R.; Martí-Gastaldo, C.; J. Am. Chem. Soc. 2008, 130, 14987; Coronado, E.; Galán-Mascarós, J. R.; Martí-Gastaldo, C.; CrystEngComm 2009, 11, 2143.

23. Pardo, E.; Ruiz-García, R.; Lloret, F.; Faus, J.; Julve, M.; Journaux, Y.; Delgado, F.; Ruiz-Pérez, C.; Adv. Mater. 2004, 16, 1597; Pardo, E.; Ruiz-García, R.; Lloret, F.; Faus, J.; Julve, M.; Journaux, Y.; Novak, M. A.; Delgado F. S.; Ruiz-Pérez, C.; Chem. Eur. J. 2007, 13, 2054; Pardo, E.; Train, C.; Lescouëzec, R.; Journaux, Y.; Pasán, J.; Ruiz-Pérez, C.; Delgado, F. S.; RuizGarcía, R.; Lloret, F.; Paulsen, C.; Chem. Commun. 2010, 46, 2322.

24. Kajiwara, T.; Nakano, M.; Kaneko, Y.; Takaishi, S.; Ito, T.; Yamashita, M.; Kamiyama, A. I.; Nojiri, H.; Ono, Y.; Kojima, N.; J. Am. Chem. Soc. 2005, 127, 10150; Tanaka, H.; Kajiwara, T.; Kaneko, Y.; Takaishi, S.; Yamashita, M.; Polyhedron 2007, 26, 2105; Kaneko, Y.; Kajiwara, T.; Yamane, H.; Yamashita, M.; Polyhedron 2007, 26, 2074.

25. Zheng, Y. Z.; Tong, M. L.; Zhang, W. X.; Chen, X. M.; Angew. Chem., Int. Ed. 2006, 45, 6310; Li, X. J.; Wang, X. Y.; Gao, S.; Cao, R.; Inorg. Chem. 2006, 45, 1508; Huang, Y. G.; Wang, X. T.; Jiang, F. L.; Gao, S.; Wu, M. Y.; Gao, Q.; Wei, W.; Hong, 
M. C.; Chem. Eur. J. 2008, 14, 10340; Hu, S.; Yun, L.; Zheng, Y. Z.; Lan, Y. H.; Powell, A. K.; Tong, M. L.; Dalton Trans. 2009, 1897.

26. Sun, Z. M.; Prosvirin, A. V.; Zhao, H. H.; Mao, J. G.; Dunbar, K. R.; J. Appl. Phys. 2005, 97, 10B305; Palii, A. V.; Ostrovsky, S. M.; Klokishner, S. I.; Reu, O. S.; Sun, Z. M.; Prosvirin, A. V.; Zhao, H. H.; Gao, J.; Dunbar, K. R.; J. Phys. Chem. A 2006, 110, 14003; Bernot, K.; Luzon, J.; Sessoli, R.; Vindigni, A.; Thion, J.; Richeter, S.; Leclercq, D.; Larionova, J.; Lee, A.; J. Am. Chem. Soc. 2008, 130, 1619; Palii, A. V.; Reu, O. S.; Ostrovsky, S. M.; Klokishner, S. I.; Tsukerblat, B. S.; Sun, Z. M.; Mao, J. G.; Prosvirin, A. V.; Zhao, H. H.; Dunbar, K. R.; J. Am. Chem. Soc. 2008, 130, 14729.

27. Lloret, F.; Ruiz, R.; Julve, M.; Faus, J.; Journaux, Y.; Castro I.; Verdaguer, M.; Chem. Mater. 1992, 4, 1150.

28. Brauer, G.; Handbook of Preparative Inorganic Chemistry, vol. 2, Academic Press: New York and London, 1963, p. 1013.

29. Cervera, B.; Ruiz, R.; Lloret, F.; Julve, M.; Cano, J.; Faus, J.; Bois, C.; Mrozinski, J.; J. Chem. Soc., Dalton Trans. 1997, 395

30. Earnshaw, A.; Introduction to Magnetochemistry, Academic Press: London, 1968.

31. Ruiz, R.; Surville-Barland, C.; Journaux, Y.; Colin, J. C.; Castro, I.; Cervera, B.; Julve, M.; Lloret, F.; Sapiña, F.; Chem. Mater. 1997, 9, 201.

32. Noinville, V.; Michalowicz, A.; GALAAD, Logiciels pour la Chimie, Société Française de Chimie: Paris, 1991, p. 116-117; Michalowicz, M.; EXAFS pour le MAC, In Logiciels pour la Chimie, Société Française de Chimie: Paris, 1991, p. 102-103.

33. Roe, A. L.; Schneider, D. J.; Mayer, R. J.; Pyrz, J. W.; Widom, J.; Que, L. J.; J. Am. Chem. Soc. 1984, 106, 1676.

34. Kosugi, N.; Yokoyama, T.; Asakuna, K.; Kuroda, H.; Chem. Phys. 1984, 91, 249; Smith, T. A.; Penner-Hahn, J. E.; Berding, M. A.; Doniach, S.; Hodgson, K. O.; J. Am. Chem. Soc. 1985, 107, 5945.

35. Cartier, C.; Verdaguer, M.; Menage, S.; Girerd, J. J.; Tuchagues, J. P.; Mabad, B.; Journal de Physique Archives (Journal de Physique Colloques) 1986, 47, C8-623.

36. Rakotonandasana, A.; Boinnard, D.; Savariault, J.-M.; Tuchages, J.-P.; Petrouleas, V.; Cartier, C.; Verdaguer, M.; Inorg. Chim. Acta 1991, 180, 19.
37. Real, J. A.; Castro, I.; Bousseksou, A.; Verdaguer, M.; Burriel, R.; Castro, M.; Linares, J.; Varret, F.; Inorg. Chem. 1997, 36, 455.

38. Natoli, C. R.; Benfatto, M.; Doniach, S.; Phys. Rev. A 1986, 34, 4682; Benfatto, M.; Natoli, C. R.; García, J.; Bianconi, A.; Marcelli, A.; Fanfoni, M.; Davoli, I.; Phys. Rev. B 1986, 34, 5774.

39. Birkelbach, F.; Winter, M.; Flörke, U.; Haupt, H. J.; Butzlaff, C.; Lengen, M; Bill, E.; Trautwein, A. X.; Wieghardt, K,; Chaudhuri, P.; Inorg. Chem. 1984, 33, 3990.

40. McKale, A. G.; Veal, B. W.; Paulikas, A. P.; J. Am. Chem. Soc. 1988, 110, 3763.

41. Seiden J.; J. Phys. Lett. 1983, 44, L947.

42. Fisher, M. E.; Am. Chem. Phys. 1964, 32, 343.

43. Caneschi, A.; Gatteschi, D.; Melandri, M. C.; Rey, P.; Sessoli, R.; Inorg. Chem. 1990, 29, 4228; Lloret, F.; Julve, M.; Ruiz, R.; Journaux, Y.; Nakatani, K.; Kahn, O.; Sletten, J.; Inorg. Chem. 1993, 32, 27.

44. Lloret, F.; Ruiz, R.; Cervera, B.; Castro, I.; Julve, M.; Faus, J.; Real, J. A.; Sapiña, F.; Journaux, Y.; Colin, J. C.; Verdaguer, M.; J. Chem. Soc., Chem. Comm. 1994, 2615.

45. Carlin, R. L.; Magnetochemistry, SpringerVerlag: New York, 1986.

46. Styjewski, E.; Giordano, N.; Adv. Phys. 1977, 26, 487; Jacobs, I. S.; Lawrence, P. E.; Phys. Rev. 1967, 164, 866.

47. Cole, K. S.; Cole, R. H.; J. Chem. Phys. 1941, 9, 341.

48. Boettcher, C. J. F.; Theory of Electric Polarization, Elsevier: Amsterdam, 1952; Aubin, S. M.; Sun, Z.; Pardi, L.; Krzystek, J.; Folting, K.; Brunel, L. J.; Rheingold, A. L.; Christou, G.; Hendrickson, D. N.; Inorg. Chem. 1999, 38, 5329.

49. Pereira, C. L. M.; Pedroso, E. F.; Stumpf, H. O.; Novak, M. A.; Ricard, L.; Ruiz-García, R.; Rivière, E.; Journaux, Y.; Angew. Chem. Int. Edit 2004, 43, 956; Novak, M.; J. Magn. Magn. Mater. 2004, 272-276, e707.

Submitted: June 28, 2010 Published online: March 1, 2011 


\section{Slow Relaxation of the Magnetization in Oximato-Bridged Heterobimetallic Copper(II)-Manganese(III) Chains}

\section{Rafael Ruiz, ${ }^{a, b}$ Isabel Castro, ${ }^{a}$ Emilio Pardo, ${ }^{a}$ Jesús Ferrando-Soria,${ }^{a}$ Joan Cano, ${ }^{a, b}$ Francesc Lloret and Miguel Julve $e^{*, a}$}

${ }^{a}$ Departament de Química Inorgànica/Instituto de Ciencia Molecular (ICMol),

Universitat de València, C/ Catedrático José Beltrán 2, 46980 Paterna, València, Spain

${ }^{b}$ Fundación General de la Universitat de València (FGUV), Amadeo de Saboya 4, 46010 València, Spain

(a)
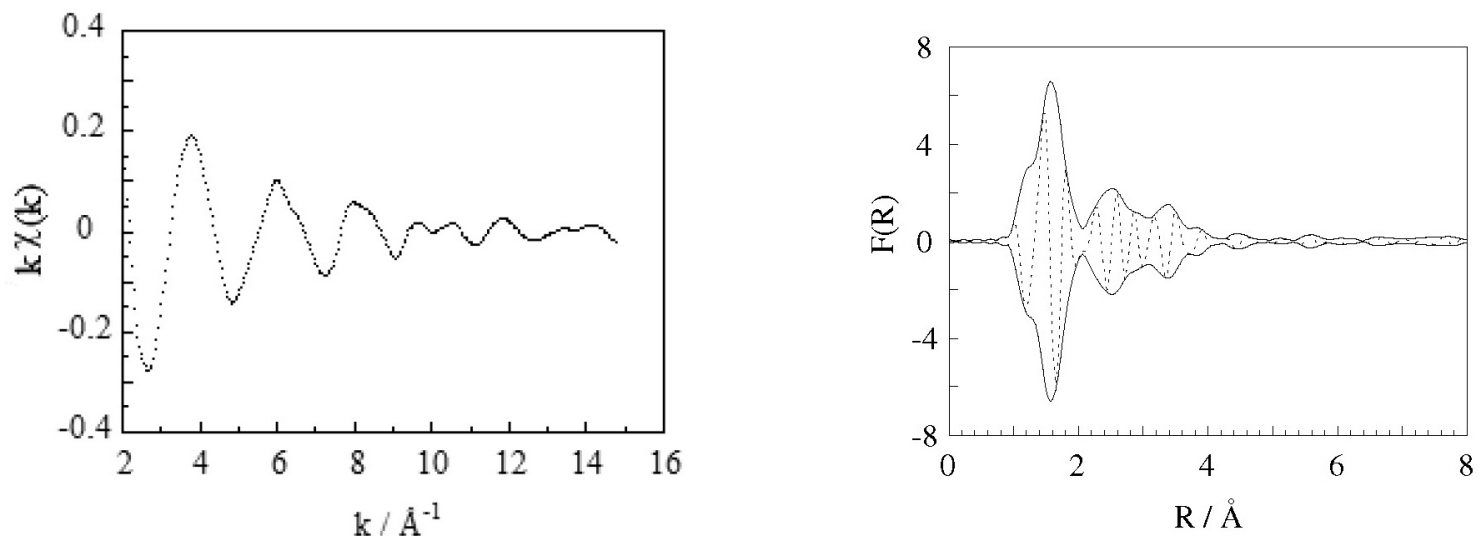

(b)
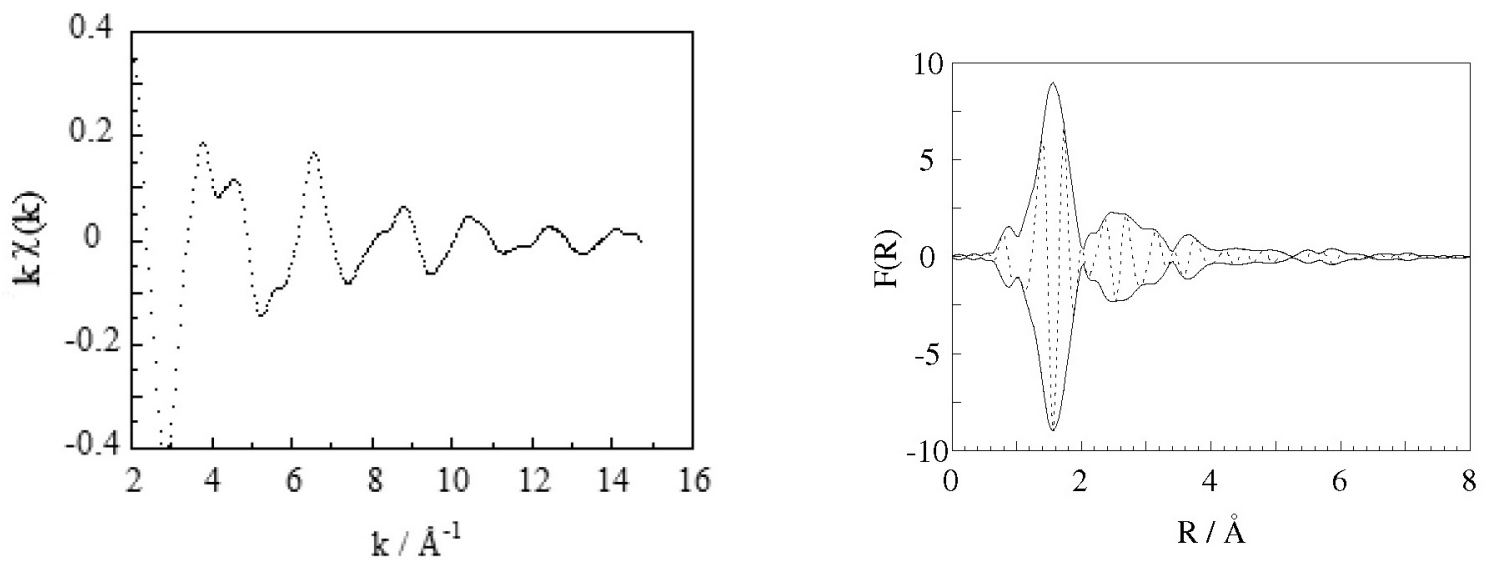

Figure S1. $k$-space experimental EXAFS spectra $\mathrm{k} \chi(\mathrm{k}) v s . \mathrm{k}$ (left) and the corresponding Fourier transforms (right) at the copper (a) and manganese (b) $\mathrm{K}$-edges for $\mathbf{2}$ at $40 \mathrm{~K}$. 
(a)
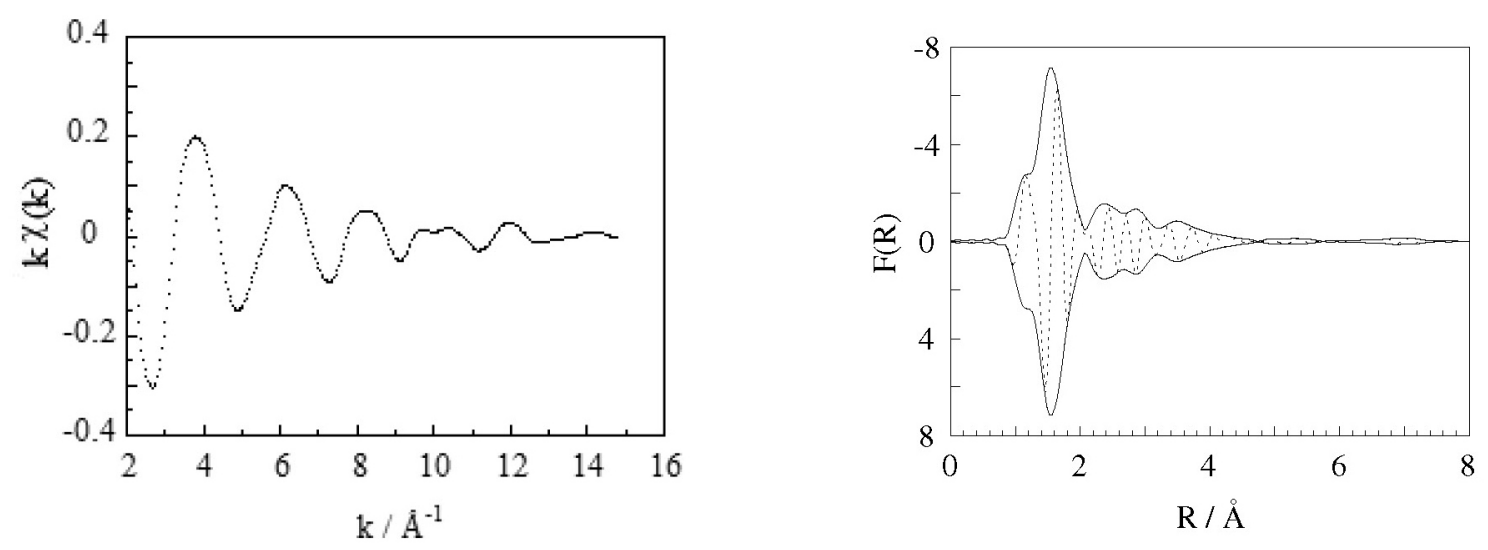

(b)
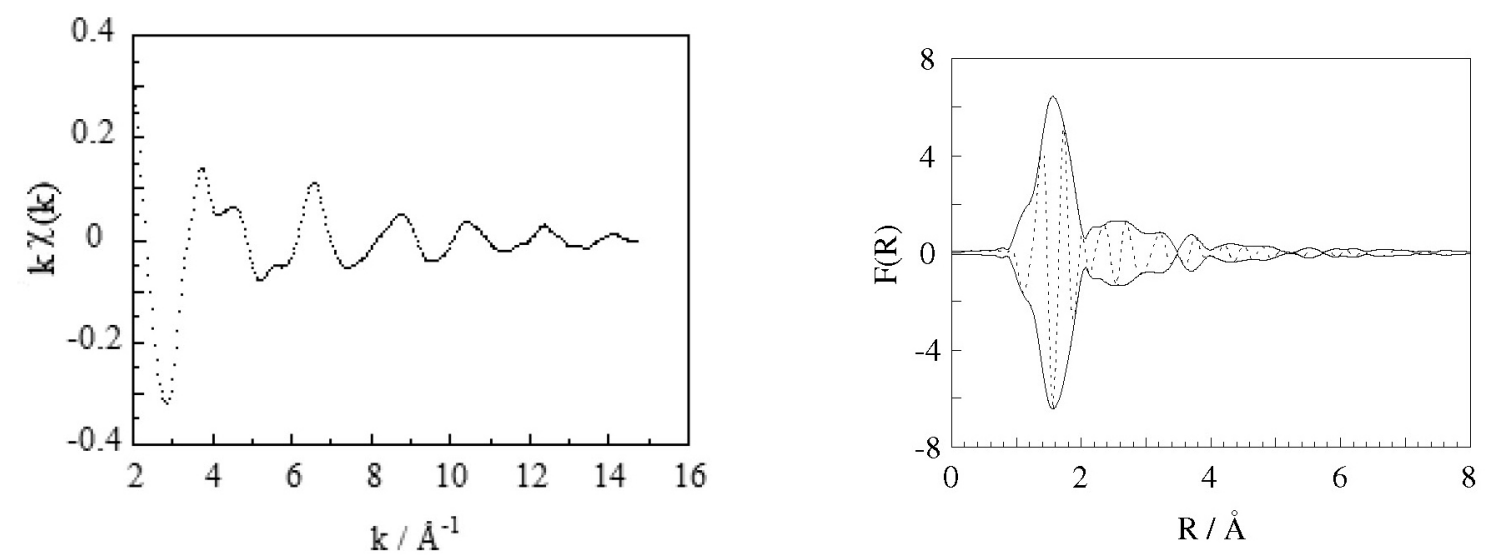

Figure S2. $k$-space experimental EXAFS spectra $k \chi(k) v s . k$ (left) and the corresponding Fourier transforms (right) at the copper (a) and manganese (b) $\mathrm{K}$-edges for 3 at $40 \mathrm{~K}$. 

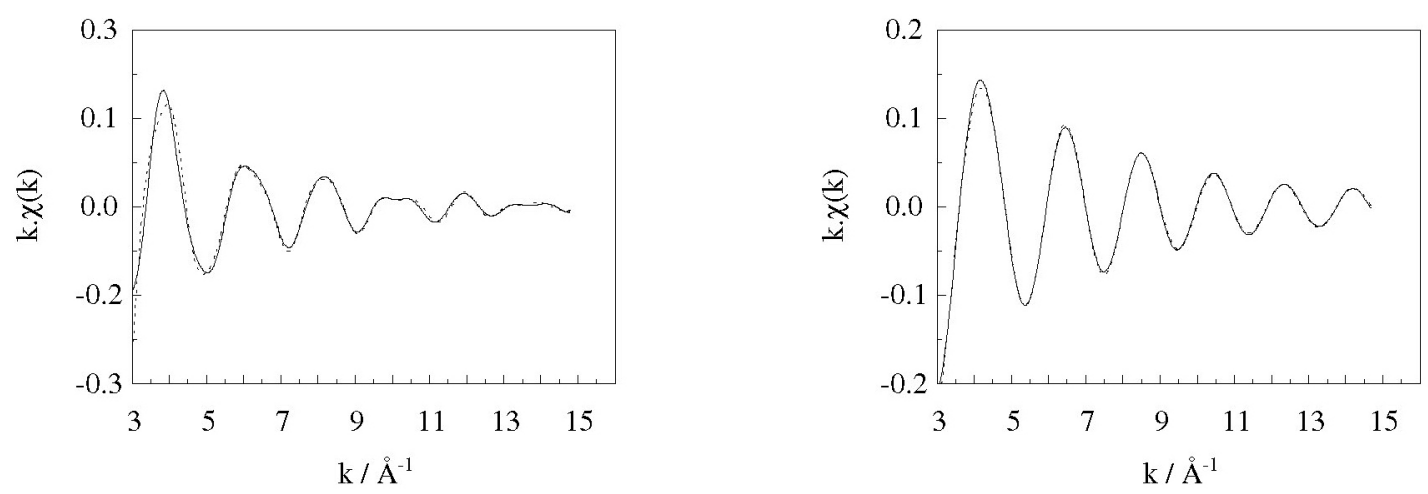

2
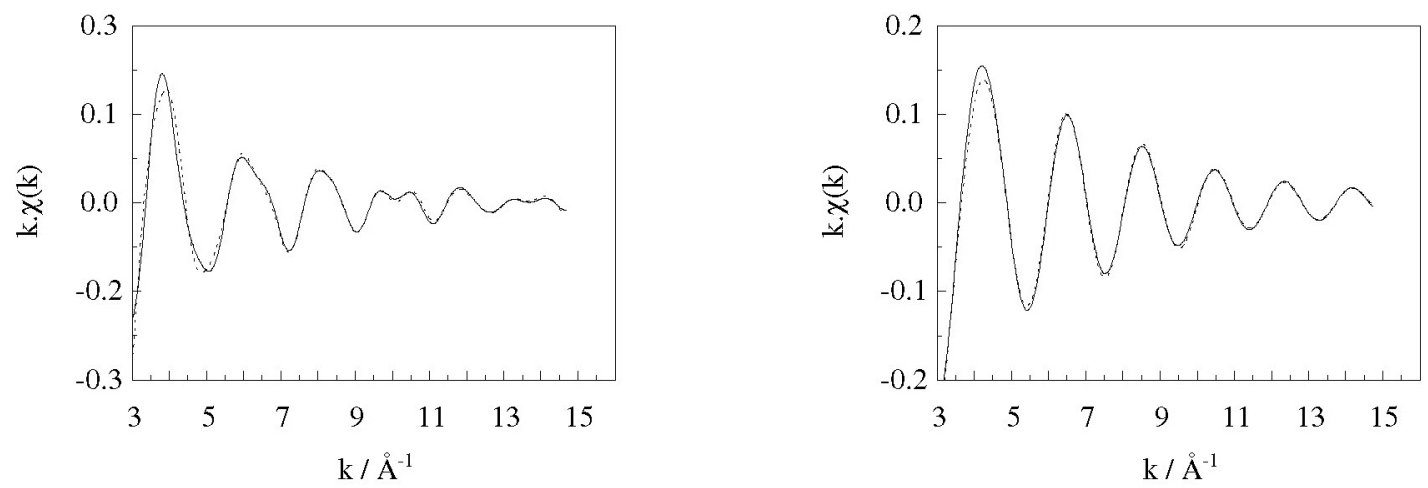

3
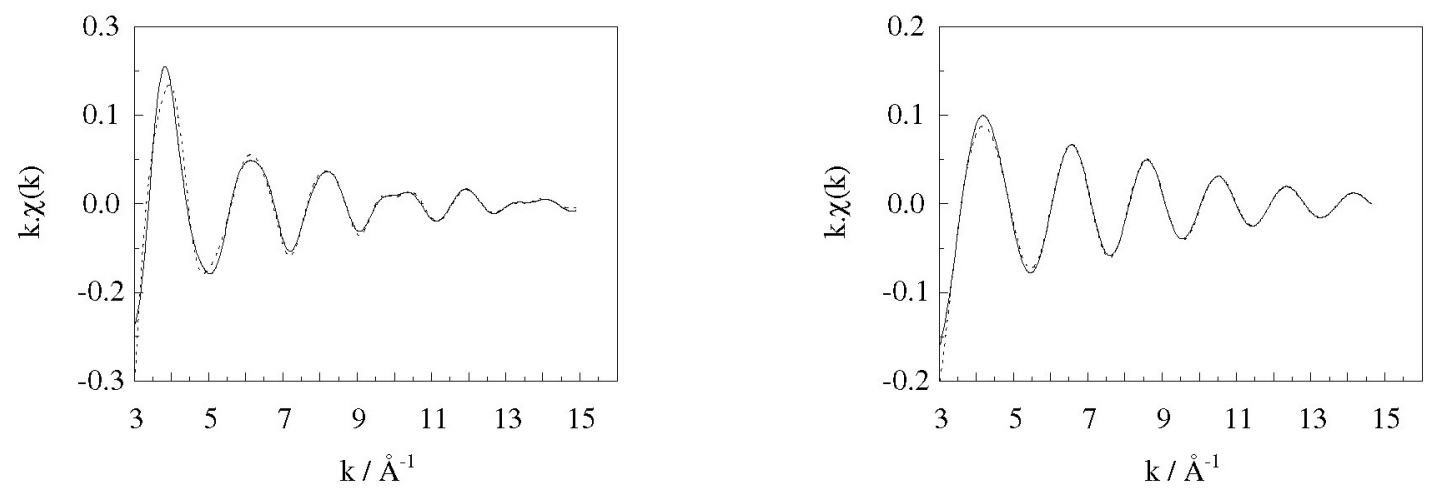

Figure S3. Experimental first-shell filtered data (dashed line) and best-fit (solid line) modelled contributions for 1-3 at the copper (left) and manganese (right) K-edges. 


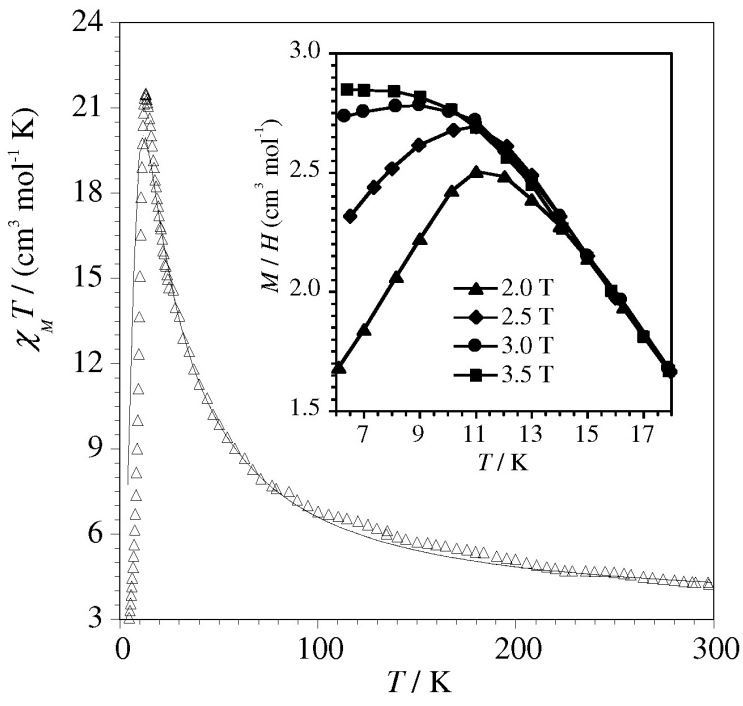

Figure S4. Temperature dependence of the $\chi_{\mathrm{M}} T$ product for $\mathbf{2}$ at $2000 \mathrm{G}$ : $(\Delta)$ experimental; $(-)$ calculated curve as discussed in the text. The inset shows the field dependence of $M / H$ of $\mathbf{2}$ in the low temperature region (the solid lines are eye-guides).

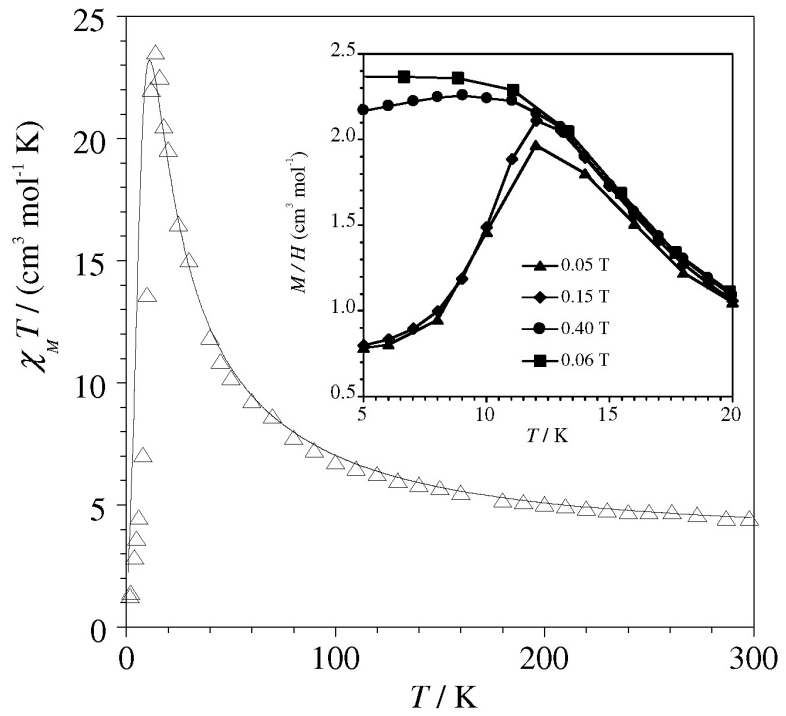

Figure S5. Temperature dependence of the $\chi_{\mathrm{M}} T$ product for 3 at $500 \mathrm{G}$ : $(\Delta)$ experimental; $(-)$ calculated curve as discussed in the text. The inset shows the field dependence of $M / H$ of $\mathbf{3}$ in the low temperature region (the solid lines are eye-guides).

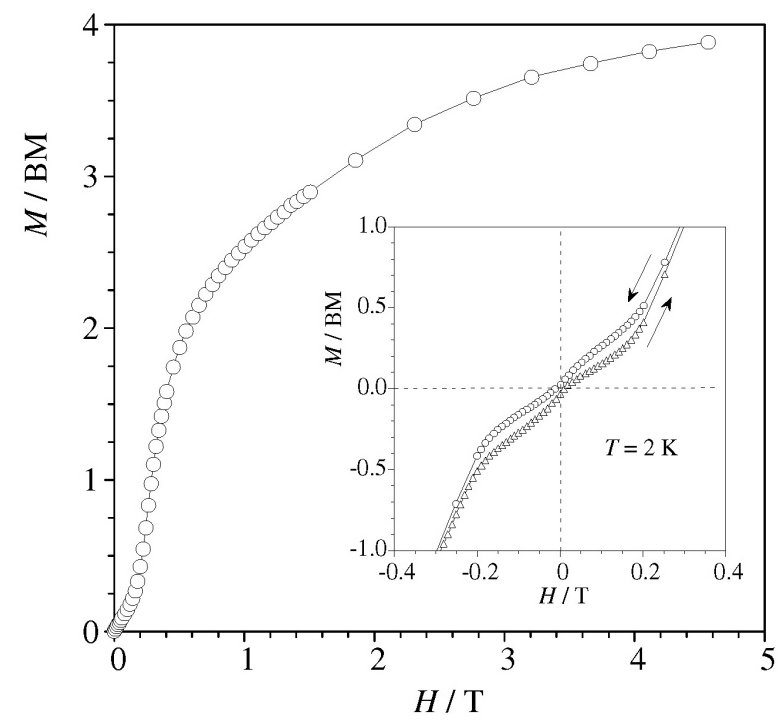

Figure S6. Magnetization $v s . H$ plot for 2 at $2.0 \mathrm{~K}$ : (o) experimental; (-) eye-guide. The inset shows the hysteresis loop of $\mathbf{2}$ at very low magnetic fields.

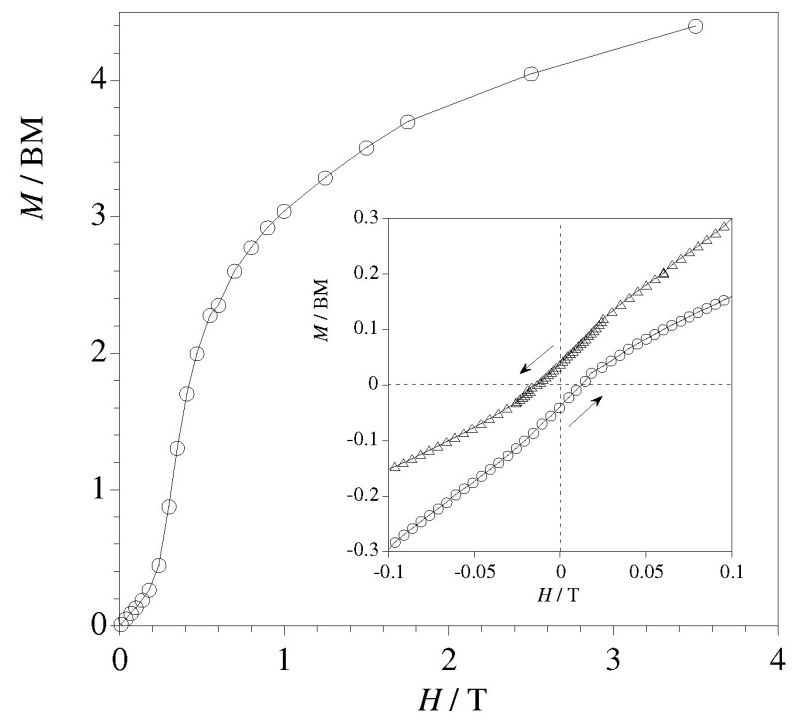

Figure S7. Magnetization $v s$. $H$ plot for 3 at $2.0 \mathrm{~K}$ : (o) experimental; (-) eye-guide. The inset shows the hysteresis loop of $\mathbf{3}$ at very low magnetic fields. 


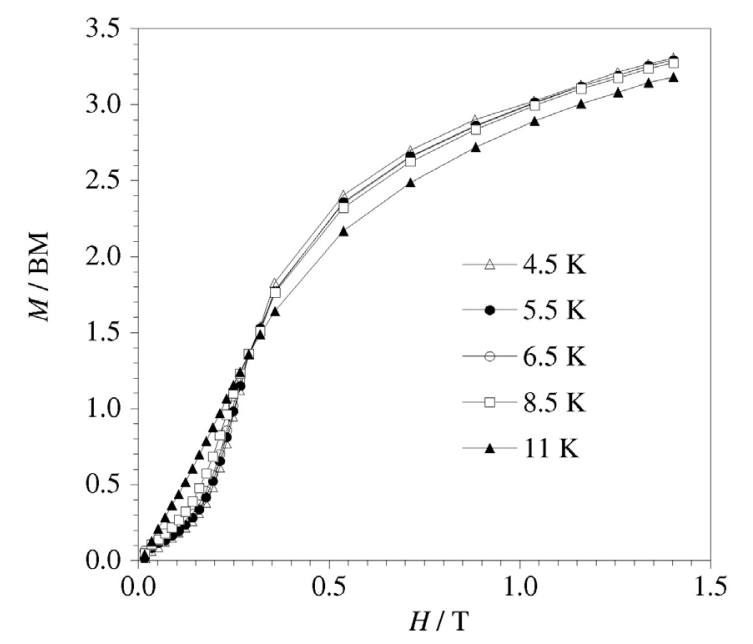

Figure S8. Magnetization isotherms for $\mathbf{2}$ at the indicated temperatures.

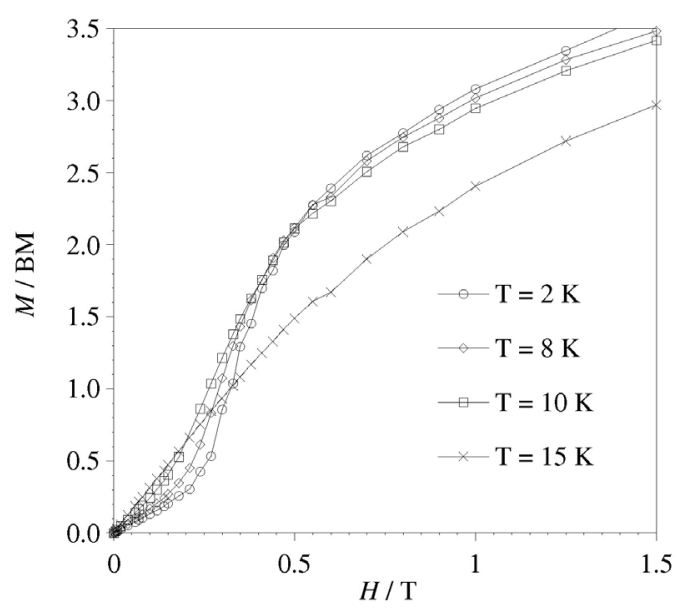

Figure S9. Magnetization isotherms for $\mathbf{3}$ at the indicated temperatures.

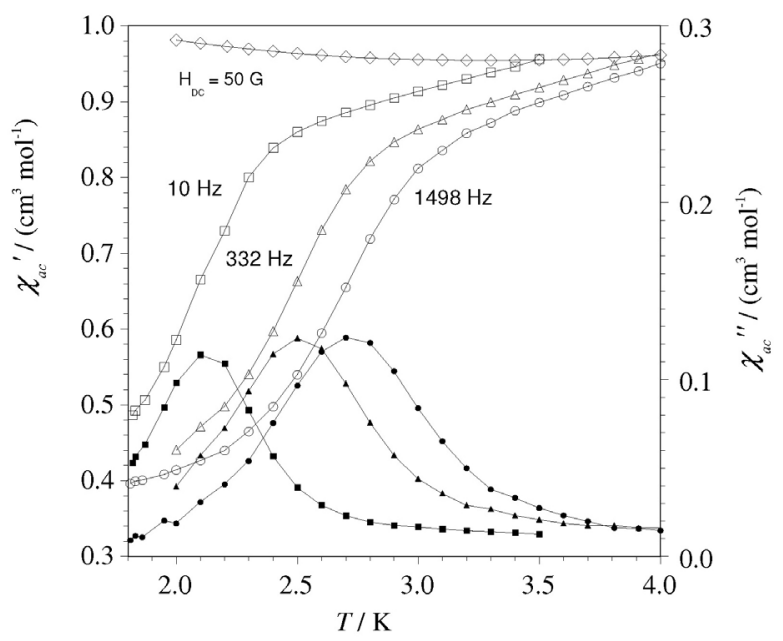

Figure S10. Field-cooled magnetization of $\mathbf{2}$ under an applied dc field of $50 \mathrm{G}$ and temperature dependence of the in-phase $\left(\chi_{\mathrm{M}}{ }^{\prime}\right)$ and out-of-phase $\left(\chi_{\mathrm{M}}{ }^{\prime \prime}\right)$ ac signals in zero applied static field and under $1 \mathrm{G}$ oscillating field at different frequencies.

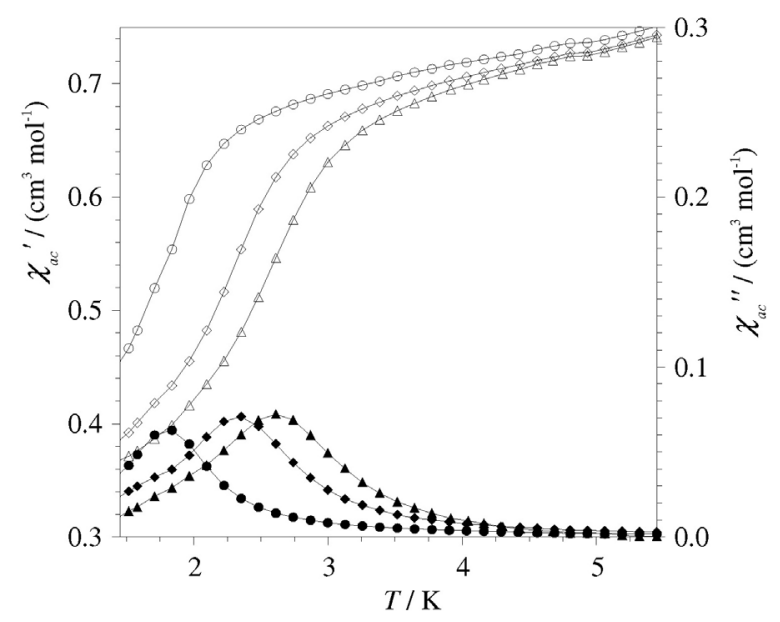

Figure S11. Temperature dependence of the in-phase $\left(\chi_{M}{ }^{\prime}\right)$ and out-of-phase $\left(\chi_{\mathrm{M}}{ }^{\prime \prime}\right)$ ac signals in zero applied static field and under $1 \mathrm{G}$ oscillating field at different frequencies. 


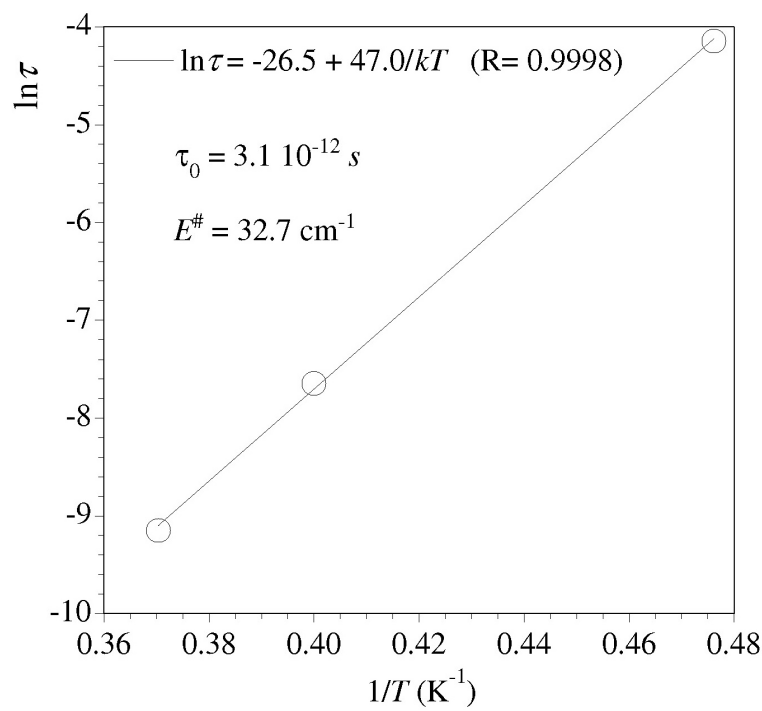

Figure S12. Arrhenius plot for 2 .

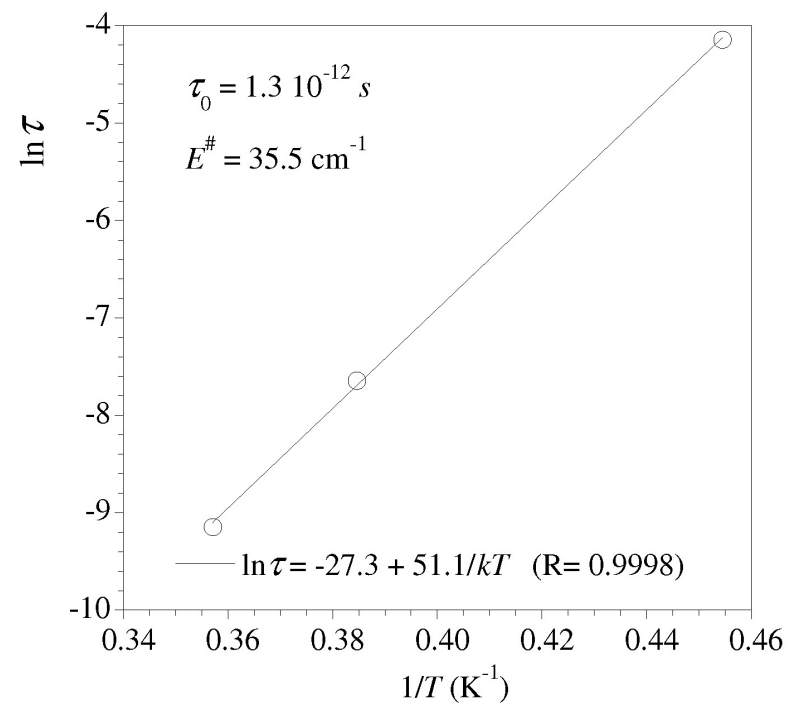

Figure S13. Arrhenius plot for 3 . 